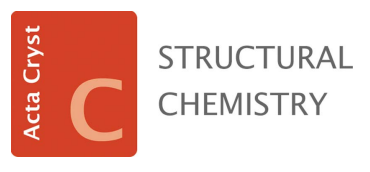

ISSN 2053-2296

Received 19 February 2020

Accepted 3 April 2020

Edited by D. S. Yufit, University of Durham, England

Keywords: 7-iodo-5-aza-7-deazaguanosine; ribonucleoside; crystal structure; Hirshfeld surface analysis; base-pair prediction; crystal packing; all-purine RNA; $\mathrm{p} K_{a}$ values.

CCDC reference: 1950946

Supporting information: this article has supporting information at journals.iucr.org/c

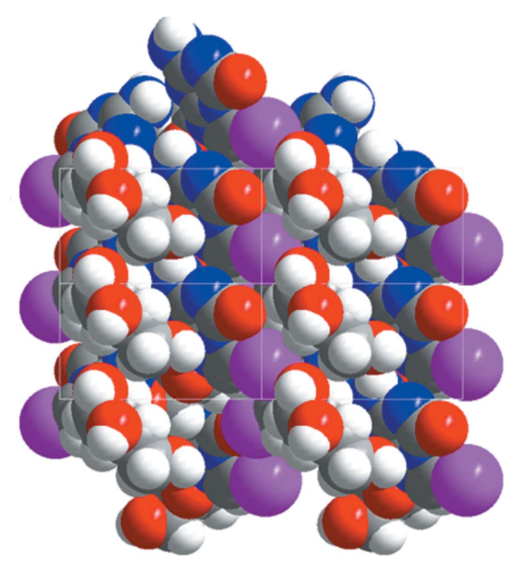

OPEN $\odot$ ACCESS

\section{7-lodo-5-aza-7-deazaguanine ribonucleoside: crystal structure, physical properties, base-pair stability and functionalization}

\author{
Dasharath Kondhare, ${ }^{\text {a }}$ Simone Budow-Busse, ${ }^{\text {a }}$ Constantin Daniliuc ${ }^{\mathrm{b}}$ and Frank \\ Seela ${ }^{\mathrm{a}, \mathrm{c} *}$
}

\begin{abstract}
a'Laboratory of Bioorganic Chemistry and Chemical Biology, Center for Nanotechnology, Heisenbergstrasse 11, 48149 Münster, Germany, '⿳O Organisch-Chemisches Institut, Westfälische Wilhelms-Universität Münster, Corrensstrasse 40, 48149 Münster, Germany, and ' ${ }^{C}$ Laboratorium für Organische und Bioorganische Chemie, Institut für Chemie, Universität Osnabrück, Barbarastrasse 7, 49069 Osnabrück, Germany. *Correspondence e-mail: frank.seela@uni-osnabrueck.de
\end{abstract}

The positional change of nitrogen-7 of the RNA constituent guanosine to the bridgehead position-5 leads to the base-modified nucleoside 5-aza-7-deazaguanosine. Contrary to guanosine, this molecule cannot form Hoogsteen base pairs and the Watson-Crick proton donor site $\mathrm{N} 3-\mathrm{H}$ becomes a protonacceptor site. This causes changes in nucleobase recognition in nucleic acids and has been used to construct stable 'all-purine' DNA and DNA with silvermediated base pairs. The present work reports the single-crystal X-ray structure of 7-iodo-5-aza-7-deazaguanosine, $\mathrm{C}_{10} \mathrm{H}_{12} \mathrm{IN}_{5} \mathrm{O}_{5}$ (1). The iodinated nucleoside shows an anti conformation at the glycosylic bond and an $N$ conformation (O4'endo) for the ribose moiety, with an antiperiplanar orientation of the $5^{\prime}$-hydroxy group. Crystal packing is controlled by interactions between nucleobase and sugar moieties. The 7-iodo substituent forms a contact to oxygen- $2^{\prime}$ of the ribose moiety. Self-pairing of the nucleobases does not take place. A Hirshfeld surface analysis of $\mathbf{1}$ highlights the contacts of the nucleobase and sugar moiety $(\mathrm{O}-$ $\mathrm{H} \cdots \mathrm{O}$ and $\mathrm{N}-\mathrm{H} \cdots \mathrm{O}$ ). The concept of $\mathrm{p} K$-value differences to evaluate basepair stability was applied to purine-purine base pairing and stable base pairs were predicted for the construction of 'all-purine' RNA. Furthermore, the 7iodo substituent of $\mathbf{1}$ was functionalized with benzofuran to detect motional constraints by fluorescence spectroscopy.

\section{Introduction}

The specific recognition of complementary nucleobases in the DNA coding system is based on the combination of purine and pyrimidine bases (Watson \& Crick, 1953). Adenine pairs with thymine and guanine with cytosine. Nevertheless, an alternative coding system entirely composed of purines ('allpurine' DNA) was suggested by Wächtershäuser (1988). In this, purines glycosylated at nitrogen-9 (adenine and guanine) base pair with purines glycosylated at nitrogen-3 (motif I xanthine and motif II isoguanine, see Fig. 1; purine numbering is used throughout this article). The resulting purine-purine base pairs are isoelectronic and isogeometric to standard purine-pyrimidine Watson-Crick pairs. However, purines glycosylated at nitrogen-3 are unstable and difficult to handle (Leonard, 2020).

Recent advances in the construction of 'all-purine' DNA used purine nucleosides glycosylated at nitrogen-9 (Seela $e t$ al., 1997, 2001; Seela \& Melenewski, 1999; Seela \& Rosemeyer, 2002). In this context, 5-aza-7-deazaguanine (imidazo[1,2-a]-1,3,5-triazine) 2'-deoxyribonucleoside (2b) has emerged as a promising purine analogue mimicking the pyrimidine site of a Watson-Crick base pair (Fig. 2). More specifically, 
5-aza-7-deazaguanine is able to pair with isoguanine or guanine (Seela \& Rosemeyer, 2002). The 5-aza-7-deazaguanineisoguanine base pair forms stable 'all-purine' DNA with an antiparallel strand orientation (motif III, Fig. 1), whereas the 5-aza-7-deazaguanine-guanine pair leads to DNA with parallel strands (motif IV, Fig. 1). Furthermore, a configurational change at the anomeric centre from $\beta$-D to $\alpha$-D resulted in heterochiral 'all-purine' DNA causing an additional change of the strand orientation (Seela et al., 2001). Size expansion of the double helix was studied with tricyclic purine bases (Winnacker \& Kool, 2013).
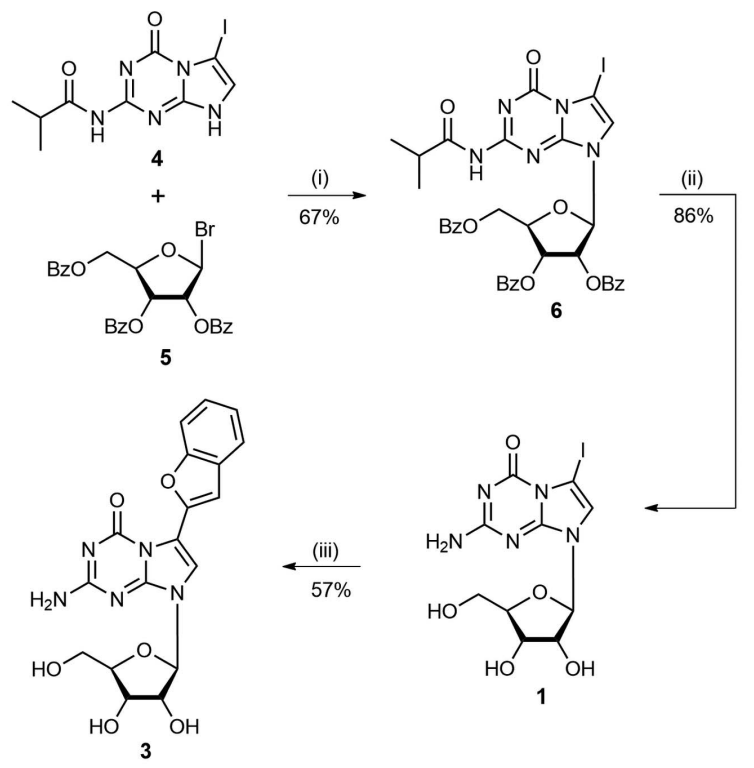

Reagents and conditions: (i) TDA-1, $\mathrm{K}_{2} \mathrm{CO}_{3}, 4 \mathrm{~h}$, r.t. (Leonard et al., 2019); (ii) $\mathrm{NH}_{3} / \mathrm{MeOH}, 24$ h, r.t. (Leonard et al., 2019); (iii) $\mathrm{Pd}\left(\mathrm{PPh}_{3}\right)_{4}, \mathrm{Na}_{2} \mathrm{CO}_{3} \cdot 10 \mathrm{H}_{2} \mathrm{O}$, benzofuran-2-boronic acid, $\mathrm{CH}_{3} \mathrm{CN} / \mathrm{H}_{2} \mathrm{O}$ (1:1), reflux, $30 \mathrm{~min}$

\section{Scheme 1}

Contrary to the work performed on 'all-purine' DNA, very little is known in the realm of 'all-purine' RNA. Iodinated

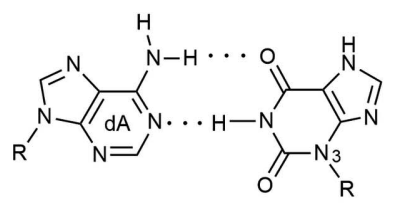

motif I

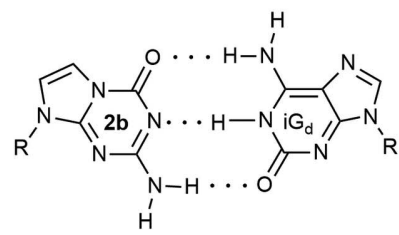

motif III: aps orientation
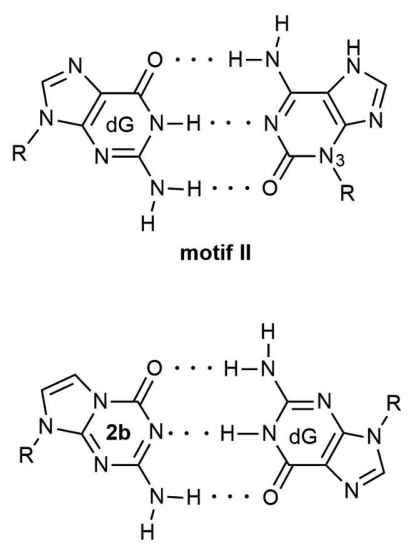

motif IV: ps orientation
Figure 1

Upper row: 'all-purine' pairs suggested by Wächtershäuser (1988). Lower row: purine-purine base pairing motifs of 5-aza-7-deazaguanine 2'-deoxyribonucleoside (2b) with antiparallel (aps) or parallel (ps) strand orientation (Seela et al., 2001). Notes: $\mathrm{iG}_{\mathrm{d}}=2^{\prime}$-deoxyisoguanosine, $\mathrm{dG}=$ $2^{\prime}$-deoxyguanosine and $\mathrm{R}=\beta$-D-2'-deoxyribofuranosyl.

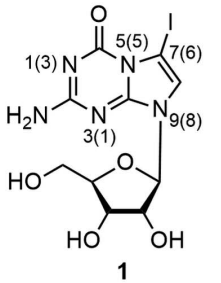

purine numbering (systematic numbering)

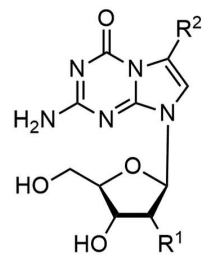

2a: $\mathrm{R}^{1}=\mathrm{OH}, \mathrm{R}^{2}=\mathrm{H}$ b: $R^{1}=H, R^{2}=H$ c: $R^{1}=H, R^{2}=$ I

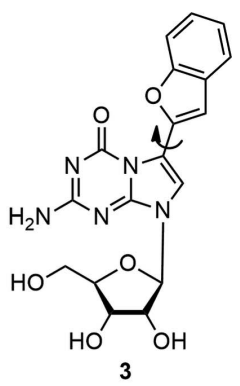

Figure 2

5-Aza-7-deazaguanine nucleosides.

5-aza-7-deazaguanine ribonucleoside 1 represents a convertible key compound within a series of 5-aza-7-deazaguanine nucleosides such as 2a-2c (Fig. 2). It has the capability to be functionalized at position-7 of the nucleobase with various functional groups and can be cross-linked at this position. Nucleosides $\mathbf{1}$ and $\mathbf{2 a}$ represent building blocks for the construction of 'all-purine' RNA. This work reports the singlecrystal X-ray structure of the 7-iodo ribonucleoside 1 (Fig. 2) and its physical properties. The crystal packing has been studied and a Hirshfeld surface analysis performed to visualize packing interactions. Base-pair stabilities are predicted on the basis of differences of the $\mathrm{p} K_{a}$ values (Krishnamurthy, 2012). Functionalization of $\mathbf{1}$ with a fluorescent group by crosscoupling has been performed and fluorescence data are collected.

\section{Experimental}

\subsection{Synthesis and crystallization of nucleoside 1}

7-Iodo-5-aza-7-deazaguanine (1) was synthesized as reported previously (Leonard et al., 2019). For crystallization, compound 1 was dissolved in a methanol/water $(1: 1 \mathrm{v} / \mathrm{v})$ mixture $(10 \mathrm{mg}$ in $1 \mathrm{ml})$ and was obtained as colourless thin needles (m.p. $180-181^{\circ} \mathrm{C}$, decomposition) by slow evaporation of the solvent (room temperature, $24 \mathrm{~h}$ ). A colourless needle-like specimen of $\mathbf{1}$ was used for the X-ray crystallographic analysis.

\subsection{X-ray diffraction and refinement}

Crystal data, data collection and structure refinement details are summarized in Table 1 . The $\mathrm{H}$ atoms on N2, O2', $\mathrm{O}^{\prime}$ and $\mathrm{O}^{\prime}$ were refined freely, but with $\mathrm{N}-\mathrm{H}$ and $\mathrm{O}-\mathrm{H}$ distance restraints and $U_{\text {iso }}(\mathrm{H})$ values fixed. For atom $\mathrm{C1}^{\prime}$, the anisotropic displacement parameters were refined with damping in order to hold this atom positive definite.

\subsection{Synthesis of benzofuran conjugate 3}

For the preparation of 2-amino-6-(benzofuran-2-yl)-8-( $\beta$-Dribofuranosyl)-8H-imidazo[1,2-a]-s-triazin-4-one (3), compound 1 (Leonard et al., 2019; $100 \mathrm{mg}, 0.24 \mathrm{mmol}$ ), $\mathrm{Pd}\left(\mathrm{PPh}_{3}\right)_{4}$ 
Table 1

Experimental details.

\begin{tabular}{|c|c|}
\hline \multicolumn{2}{|l|}{ Crystal data } \\
\hline Chemical formula & $\mathrm{C}_{10} \mathrm{H}_{12} \mathrm{IN}_{5} \mathrm{O}_{5}$ \\
\hline$M_{\mathrm{r}}$ & 409.15 \\
\hline Crystal system, space group & Monoclinic, $P 2_{1}$ \\
\hline Temperature $(\mathrm{K})$ & 100 \\
\hline$a, b, c(\AA)$ & $9.1086(2), 6.3149(2), 11.0428(3)$ \\
\hline$\beta\left(^{\circ}\right)$ & $95.585(1)$ \\
\hline$V\left(\AA^{3}\right)$ & $632.17(3)$ \\
\hline$Z$ & 2 \\
\hline Radiation type & $\mathrm{Cu} K \alpha$ \\
\hline$\mu\left(\mathrm{mm}^{-1}\right)$ & 20.25 \\
\hline Crystal size $(\mathrm{mm})$ & $0.35 \times 0.06 \times 0.02$ \\
\hline \multicolumn{2}{|l|}{ Data collection } \\
\hline Diffractometer & Bruker KappaCCD APEXII \\
\hline Absorption correction & $\begin{array}{l}\text { Multi-scan (SADABS; Bruker, } \\
\text { 2014) }\end{array}$ \\
\hline$T_{\min }, T_{\max }$ & $0.39,0.69$ \\
\hline $\begin{array}{l}\text { No. of measured, independent and } \\
\text { observed }[I>2 \sigma(I)] \text { reflections }\end{array}$ & $15087,2216,2144$ \\
\hline$R_{\text {int }}$ & 0.072 \\
\hline$(\sin \theta / \lambda)_{\max }\left(\AA^{-1}\right)$ & 0.597 \\
\hline \multicolumn{2}{|l|}{ Refinement } \\
\hline$R\left[F^{2}>2 \sigma\left(F^{2}\right)\right], w R\left(F^{2}\right), S$ & $0.036,0.097,1.07$ \\
\hline No. of reflections & 2216 \\
\hline No. of parameters & 205 \\
\hline No. of restraints & 12 \\
\hline $\mathrm{H}$-atom treatment & $\begin{array}{l}\mathrm{H} \text { atoms treated by a mixture of } \\
\text { independent and constrained } \\
\text { refinement }\end{array}$ \\
\hline$\Delta \rho_{\max }, \Delta \rho_{\min }\left(\mathrm{e} \AA^{-3}\right)$ & $2.79,-1.19$ \\
\hline Absolute structure & $\begin{array}{l}\text { Flack } x \text { determined using } 919 \\
\quad \text { quotients }\left[\left(I^{+}\right)-\left(I^{-}\right)\right] / \\
{\left[\left(I^{+}\right)+\left(I^{-}\right)\right](\text {Parsons } \text { et al., 2013) }}\end{array}$ \\
\hline Absolute structure parameter & $0.040(7)$ \\
\hline
\end{tabular}

Computer programs: SAINT (Bruker, 2015), SHELXT2014 (Sheldrick, 2015a), SHELXL2014 (Sheldrick, 2015b), APEX3 (Bruker, 2016) and XP (Bruker, 1998).

(28 mg, $0.024 \mathrm{mmol}), \mathrm{Na}_{2} \mathrm{CO}_{3} \cdot 10 \mathrm{H}_{2} \mathrm{O}(352 \mathrm{mg}, 1.23 \mathrm{mmol})$ and benzofuran-2-boronic acid $(158 \mathrm{mg}, 0.97 \mathrm{mmol})$ in $\mathrm{CH}_{3} \mathrm{CN} /$ $\mathrm{H}_{2} \mathrm{O}(1: 1 v / v, 20 \mathrm{ml})$ were refluxed for $30 \mathrm{~min}$. After consumption of starting material $\mathbf{1}$ [monitored by thin-layer chromatography (TLC)], the solvent of the reaction mixture was evaporated under reduced pressure, and the residue was applied to flash chromatography $\left(\mathrm{CH}_{2} \mathrm{Cl}_{2} / \mathrm{MeOH}, 90: 10 \rightarrow\right.$ $75: 25 v / v)$. Compound 3 was obtained from the main zone as a white solid (yield $55 \mathrm{mg}, 57 \%$ ). TLC (silica gel, $\mathrm{CH}_{2} \mathrm{Cl}_{2} /$ $\mathrm{MeOH}, 85: 15 v / v) R_{\mathrm{F}}$ 0.4. $\lambda_{\max }(\mathrm{MeOH}) / \mathrm{nm} 312\left(\varepsilon / \mathrm{dm}^{3} \mathrm{~mol}^{-1}\right.$ $\left.\mathrm{cm}^{-1}, 22600\right), 327$ (18800). ${ }^{1} \mathrm{H}$ NMR (600 MHz, DMSO- $\left.d_{6}\right): \delta$ $8.00(s, 1 \mathrm{H}, \mathrm{H}-8), 7.71-7.65(m, 2 \mathrm{H}$, benzofuran Ar-H), 7.54 $(d q, J=8.4,1.0 \mathrm{~Hz}, 1 \mathrm{H}$, benzofuran $\mathrm{Ar}-\mathrm{H}), 7.33$ ( $d d d, J=8.4$, 7.2, 1.3 Hz, 1H, benzofuran Ar-H), $7.26(t d, J=7.4,1.0 \mathrm{~Hz}, 1 \mathrm{H}$, benzofuran Ar-H), $7.12\left(s, 2 \mathrm{H}, \mathrm{NH}_{2}\right), 5.87(d, J=5.8 \mathrm{~Hz}, 1 \mathrm{H}$, $\left.\mathrm{H}-1^{\prime}\right), 5.51\left(d, J=5.5 \mathrm{~Hz}, 1 \mathrm{H}, \mathrm{OH}-2^{\prime}\right), 5.20(d, J=4.6 \mathrm{~Hz}, 1 \mathrm{H}$, $\left.\mathrm{OH}-3^{\prime}\right), 5.16\left(t, J=5.3 \mathrm{~Hz}, 1 \mathrm{H}, \mathrm{OH}-5^{\prime}\right), 4.37(q, J=5.4 \mathrm{~Hz}, 1 \mathrm{H}$, $\left.\mathrm{H}-2^{\prime}\right), 4.11\left(t d, J=4.7,3.4 \mathrm{~Hz}, 1 \mathrm{H}, \mathrm{H}-3^{\prime}\right), 3.92(q, J=3.6 \mathrm{~Hz}, 1 \mathrm{H}$, $\left.\mathrm{H}-4^{\prime}\right), 3.66\left(d d d, J=11.9,5.2,3.8 \mathrm{~Hz}, 1 \mathrm{H}, \mathrm{H}-5^{\prime}\right), 3.58(d d d, J=$ 11.9, 5.3, 3.6 Hz, 1H, H-5'). ${ }^{13} \mathrm{C}$ NMR (151 MHz, DMSO- $\left.d_{6}\right): \delta$ 164.8, 153.9, 151.9, 150.1, 144.7, 128.4, 125.1, 123.2, 121.6, 115.7, 114.7, 110.7, 108.2, 86.5, 85.5, 85.4, 73.7, 70.2, 61.1, 61.0. HRMS (ESI-TOF) $m / z:\left[M+\mathrm{Na}^{+}\right]$calculated for $\mathrm{C}_{18} \mathrm{H}_{17} \mathrm{~N}_{5} \mathrm{NaO}_{6}$, 422.1071; found, 422.1075.

\section{Results and discussion}

3.1. Molecular geometry and conformation of 7-iodo-5-aza7-deazaguanosine (1)

The three-dimensional (3D) structure of $\mathbf{1}$ is shown in Fig. 3(a) and selected crystallographic data and structure refinement details are summarized in Table 1. According to the Flack parameter and the synthetic pathway, the anomeric centre at $\mathrm{C}^{\prime}$ is in an $R$ configuration confirming the $\beta$-D anomeric structure of $\mathbf{1}$. The structure of the related $2^{\prime}$-deoxyribonucleoside has been reported previously (for selected geometric parameters of the single-crystal X-ray analysis of 2c, see Table S1 in the supporting information) (Leonard et al., 2019).

To evaluate the impact of the 2 -hydroxy group of ribonucleoside 1 on the crystal structure, it was of interest to compare the geometric parameters of compound $\mathbf{1}$ with those of the 2'-deoxyribonucleoside 2c (Leonard et al., 2019). An overlay of both molecules visualizes the conformational differences mainly affecting the sugar moiety (Fig. 3b).

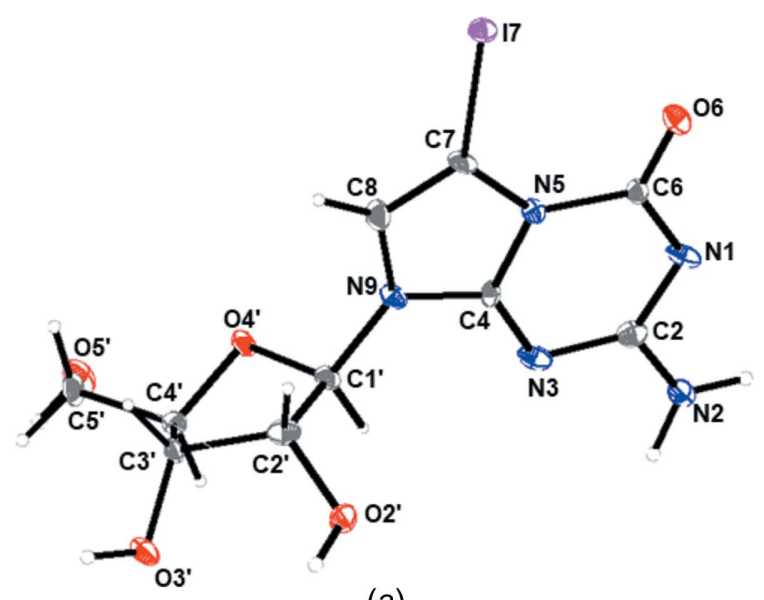

(a)

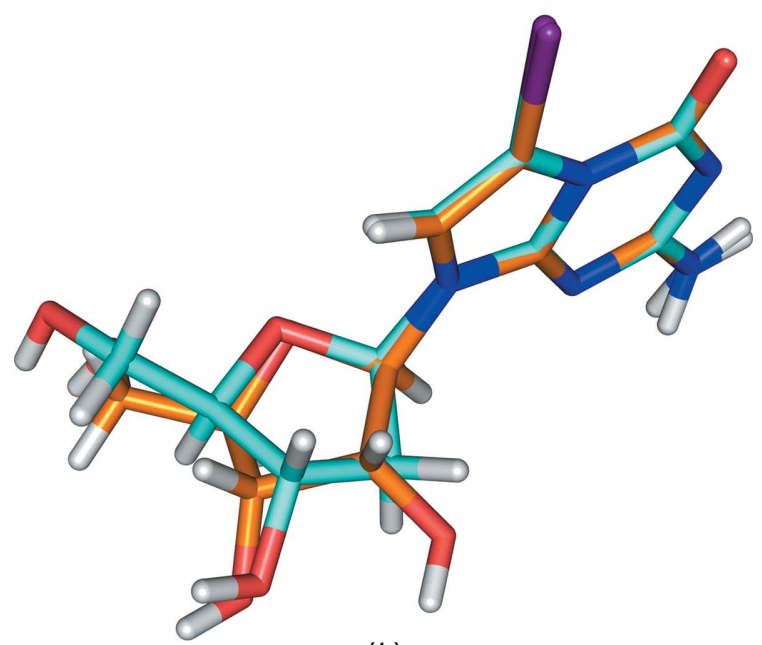

(b)

Figure 3

(a) Perspective view of $\mathbf{1}$, showing the atom-numbering scheme. Displacement ellipsoids are drawn at the $50 \%$ probability level and $\mathrm{H}$ atoms are shown as small spheres of arbitrary size. (b) Overlay of ribonucleoside $\mathbf{1}$ and the related 2 -deoxyribonucleoside $\mathbf{2 c}$. 
Table 2

Selected geometric parameters $\left(\AA{ }^{\circ}\right)$.

\begin{tabular}{|c|c|c|c|}
\hline $\mathrm{I} 7-\mathrm{C} 7$ & $2.081(10)$ & $\mathrm{N} 9-\mathrm{C1}^{\prime}$ & $1.439(12)$ \\
\hline $\mathrm{C} 4-\mathrm{N} 9-\mathrm{C1}^{\prime}$ & $123.7(8)$ & $\mathrm{O} 6-\mathrm{C} 6-\mathrm{N} 1$ & $125.1(8)$ \\
\hline $\mathrm{C} 1^{\prime}-\mathrm{O} 4^{\prime}-\mathrm{C} 4^{\prime}$ & 103.7 (7) & $\mathrm{N} 5-\mathrm{C} 7-\mathrm{I} 7$ & $126.9(7)$ \\
\hline $\mathrm{N} 2-\mathrm{C} 2-\mathrm{N} 1$ & $117.1(9)$ & $\mathrm{O}^{\prime}-\mathrm{C}^{\prime}-\mathrm{C} 4^{\prime}$ & $110.3(8)$ \\
\hline $\mathrm{C} 4^{\prime}-\mathrm{O}^{\prime}-\mathrm{C}^{\prime}-\mathrm{C}^{\prime}$ & $-41.3(9)$ & $\mathrm{C}^{\prime}-\mathrm{O} 4^{\prime}-\mathrm{C}^{\prime}-\mathrm{C}^{\prime}{ }^{\prime}$ & $47.8(9)$ \\
\hline $\mathrm{C} 4-\mathrm{N} 9-\mathrm{Cl}^{\prime}-\mathrm{O}_{4}^{\prime}$ & $-120.6(9)$ & $\mathrm{C} 2^{\prime}-\mathrm{C} 3^{\prime}-\mathrm{C} 4^{\prime}-\mathrm{O} 4^{\prime}$ & $-34.8(9)$ \\
\hline $\mathrm{O} 4^{\prime}-\mathrm{C} 1^{\prime}-\mathrm{C} 2^{\prime}-\mathrm{C} 3^{\prime}$ & $18.1(9)$ & $\mathrm{C} 3^{\prime}-\mathrm{C} 4^{\prime}-\mathrm{C} 5^{\prime}-\mathrm{O}^{\prime}{ }^{\prime}$ & $-172.9(8)$ \\
\hline $\mathrm{C} 1^{\prime}-\mathrm{C} 2^{\prime}-\mathrm{C} 3^{\prime}-\mathrm{C} 4^{\prime}$ & $9.8(10)$ & & \\
\hline
\end{tabular}

The nucleobase may adopt two principal orientations with respect to the sugar moiety (syn/anti) and it is defined by the torsion angle $\chi\left(\mathrm{O}^{\prime}-\mathrm{Cl}^{\prime}-\mathrm{N} 9-\mathrm{C} 4\right)$ (IUPAC-IUB Joint Commission on Biochemical Nomenclature, 1983). Purine nucleosides are found in a wide range of anti conformations (Blackburn et al., 2006). The 7-iodo-5-aza-7-deazaguanine moiety of both nucleosides also adopts an anti conformation, with $\chi=-120.6(9)^{\circ}$ for ribonucleoside 1 (Table 2) and $\chi=$ $-139.9(6)^{\circ}$ for 2c (Leonard et al., 2019). The glycosylic bond lengths of $\mathbf{1}$ (Table 2) and 2c (Lin et al., 2004) are within the range of purine nucleosides (Saenger, 1984).

The ribose ring is twisted out of plane to minimize steric interactions of the substituents, referred to as sugar puckering (Altona \& Sundaralingam, 1972). The more electronegative substituents of $\mathrm{C}^{\prime}$ and $\mathrm{C}^{\prime}$ prefer an axial orientation. Nucleosides can adopt two principal sugar puckering modes, namely $\mathrm{C}^{\prime}$-endo $(N)$ and $\mathrm{C} 2^{\prime}$-endo $(S)$ corresponding to the major displacement of $\mathrm{C}^{\prime}$ or $\mathrm{C}^{\prime}$ from the median $\mathrm{C}^{\prime} / \mathrm{O}^{\prime} / \mathrm{C}^{\prime}$ plane. The $\mathrm{C}^{\prime}$-endo conformation is the preferred puckering mode of 2'-deoxyribonucleosides (Saenger, 1984), whereas ribonucleosides show a preference for the $\mathrm{C}^{\prime}$-endo sugar pucker. Also, 7-iodo ribonucleoside 1 shows an $N$ conformation, with a pseudorotational phase angle $P=77.87^{\circ}$ and a maximum amplitude $\tau_{\mathrm{m}}=47.14^{\circ}$. However, the typical C3'endo conformation is less pronounced and the sugar pucker is shifted towards $\mathrm{O} 4^{\prime}$-endo. This is a sugar conformation where the nucleobase and the exocyclic $5^{\prime}-\mathrm{OH}$ group are arranged equatorially. The sugar moiety of $2^{\prime}$-deoxyribonucleoside $\mathbf{2 c}$ also adopts an $N$-type sugar conformation $\left(\mathrm{C}^{\prime}\right.$-endo-C $4^{\prime}$-exo, ${ }^{3} T_{4}, P=28.55^{\circ}$ and $\tau_{\mathrm{m}}=34.28^{\circ}$ ) (Leonard et al., 2019).

In many cases, the solid-state conformation of nucleosides differs from that in solution and is also different from that of nucleosides as constituents of a single- or double-stranded nucleic acid. Sugar puckering of $\mathbf{1}$ was determined in solution from the coupling constants of high-resolution ${ }^{1} \mathrm{H}$ NMR spectra $(600 \mathrm{MHz}$ ) (for details, see Table S2 in the supporting information). The population of $S$ versus $N$ conformers was calculated on the basis of coupling constants using the program PSEUROT (Version 6.3; Van Wijk et al., 1999). Notably, the conformation found for ribonucleoside $\mathbf{1}$ in solution is $S$-type $(69 \%)$ and is different from that in the solid state ( $N$-type). The closely related 2 -deoxyribonucleoside $\mathbf{2 c}$ also prefers an $S$ conformation $(62 \%)$ in solution (Lin et al., 2004).

The orientation of the exocyclic $5^{\prime}$-hydroxy group relative to the sugar ring is described by the torsion angle $\gamma\left(\mathrm{O}^{\prime}-\right.$
$\left.\mathrm{C}^{\prime}-\mathrm{C}^{\prime}-\mathrm{C}^{\prime}\right)$. Surprisingly, $\gamma$ is identical in both nucleosides despite the fact of their having different sugar moieties (ribose versus $2^{\prime}$-deoxyribose). The 5'-hydroxy group adopts, in both cases, an antiperiplanar (trans) conformation, with $\gamma=$ $-172.9(8)^{\circ}$ for $\mathbf{1}$ and $\gamma=-172.7$ (4) ${ }^{\circ}$ for $\mathbf{2 c}$ (Leonard et al., 2019).

\subsection{Hydrogen bonding and molecular packing}

In nucleoside solid-state structures, hydrogen bonds are formed between $\mathrm{N}$ and/or $\mathrm{O}$ atoms functioning as proton donors or acceptors. They can be provided by the nucleobases and/or the sugar moieties. Fig. 4(a) displays the hydrogenbonding pattern of 7-iodo-5-aza-7-deazaguanosine (1) within one particular layer.

Nucleobase-to-nucleobase interactions, such as self-pairing in a Watson-Crick-like fashion, are not observed for ribonucleoside 1. This is different from the solid-state structure of the 5-aza-7-deazaguanine nucleobase reported recently (Laos et al., 2019). The free nucleobase is able to adopt tautomeric forms with the $\mathrm{H}$ atom located either at N9 or at N3. The $\mathrm{N} 9-\mathrm{H}$ tautomer can base pair with the N3-H tautomer, forming a tridentate base pair (Laos et al., 2019). However, in the context of DNA or RNA structure, this is an artificial situation, as nucleosides glycosylated at N9 lose the proton at the heterocycle and thus the ability to form these tautomers.

Compound $\mathbf{1}$ forms in the crystal a core of four molecules displaying a 'parallelogram'-like arrangement, with the $\mathrm{O} 2$ ' $\mathrm{H} 2^{\prime}$ and $\mathrm{C}^{\prime}-\mathrm{H} 2^{\prime} 1$ groups as proton donors and atom $\mathrm{O} 6$ of the nucleobase as a bi-acceptor (Fig. $4 a$ and Table 3). This structure is surrounded by 'cyclohexane'-like motifs formed by two molecules connected via $\mathrm{N} 2-\mathrm{H} 2 A \cdots \mathrm{O}^{\prime i}$ and $\mathrm{C}^{\prime}{ }^{\prime}-$ $\mathrm{H} 1^{\prime} \cdots \mathrm{N} 2^{\mathrm{v}}$ hydrogen bonds. Further stabilization of the solidstate structure is achieved by hydrogen bonds formed by the exocyclic $5^{\prime}-\mathrm{OH}$ group $\left(\mathrm{N} 2-\mathrm{H} 2 \mathrm{~B} \cdots \mathrm{O}^{\prime i i}\right.$ and $\mathrm{O}^{\prime}-$ $\mathrm{H} 5^{\prime} \cdot \mathrm{O}^{\prime \text { iv }}$ ).

It is well documented that the iodo substituents of halogenated nucleosides can participate in molecular interactions, sometimes even playing a predominant role. Strong iodo-iodo interactions have been reported for 5-iodo- $\alpha$ - $2^{\prime}$-deoxycytidine (Müller et al., 2019), while the iodo substituent of $2^{\prime}$-deoxyribonucleoside $\mathbf{2 c}$ shows a strong contact to atom $\mathrm{O}^{\prime}$ $\left[\mathrm{I} 7 \cdots \mathrm{O}^{\prime}=2.794(4) \AA\right.$ and $\left.\mathrm{C} 7-\mathrm{I} 7 \cdots \mathrm{O}^{\prime}=169.2(2)^{\circ}\right]$ (Leonard et al., 2019). In the crystal structure of 7-iodo-5-aza7-deazaguanosine (1), the iodo substituent I7 shows a contact

Table 3

Hydrogen-bond geometry $\left(\AA{ }^{\circ}\right)$.

\begin{tabular}{lllll}
\hline$D-\mathrm{H} \cdots A$ & $D-\mathrm{H}$ & $\mathrm{H} \cdots A$ & $D \cdots A$ & $D-\mathrm{H} \cdots A$ \\
\hline $\mathrm{N} 2-\mathrm{H} 2 A \cdots \mathrm{O}^{\prime i}$ & $0.90(3)$ & $2.25(10)$ & $2.941(11)$ & $133(11)$ \\
$\mathrm{N} 2-\mathrm{H} 2 B \cdots 5^{\prime i i}$ & $0.90(3)$ & $2.04(5)$ & $2.905(12)$ & $160(12)$ \\
$\mathrm{O}^{\prime}-\mathrm{H}^{\prime} \cdots 6^{\text {iii }}$ & $0.87(3)$ & $1.93(8)$ & $2.689(9)$ & $144(12)$ \\
$\mathrm{O}^{\prime}-\mathrm{H}^{\prime} \cdots 3^{\prime i v}$ & $0.87(3)$ & $1.87(7)$ & $2.673(10)$ & $151(13)$ \\
$\mathrm{C}^{\prime}-\mathrm{H}^{\prime} \cdots \mathrm{N}^{\mathrm{v}}$ & 1.0 & 2.63 & $3.345(15)$ & 128 \\
$\mathrm{C}^{\prime}-\mathrm{H}^{\prime} 1 \cdots 6^{\text {vi }}$ & 1.0 & 2.57 & $3.541(12)$ & 163 \\
\hline
\end{tabular}

Symmetry codes: (i) $x, y+1, z$; (ii) $-x+1, y+\frac{3}{2},-z+1$; (iii) $x-1, y, z$; (iv) $-x, y-\frac{1}{2},-z+1 ;(\mathrm{v})-x+1, y-\frac{1}{2},-z+1 ;(\mathrm{vi})-x+1, y-\frac{1}{2},-z$. 
to atom $\mathrm{O}^{\prime}\left[2.936(7) \AA\right.$ and $\mathrm{C} 7-\mathrm{I} 7 \cdots \mathrm{O} 2^{\prime v i}=170.4(3)^{\circ}$; for symmetry code, see Table 3]. However, the I $\cdots$ O contact of ribonucleoside $\mathbf{1}$ is less strong than that in compound $\mathbf{2 c}$.

The individual nucleoside layers are stacked upon each other in a very regular fashion, as demonstrated in Fig. 4(b). Fig. 5 shows that compound $\mathbf{1}$ forms chains which are arranged in an alternating reverse fashion $(A B A B \ldots)$. Two chains $(A$ and $B)$ are connected to each other by hydrogen bonds $\left(\mathrm{Cl}^{\prime}-\right.$ $\mathrm{H}^{\prime} \cdots \mathrm{N} 2^{\mathrm{v}}, \mathrm{N} 2-\mathrm{H} 2 B \cdots \mathrm{O}^{\prime i \mathrm{ii}}$ and $\mathrm{O}^{\prime}-\mathrm{H}^{\prime} \cdots \mathrm{O}^{\prime \text { iv }}$; Table 3$)$. However, as was discussed above, the ribonucleoside molecules are not arranged in a Watson-Crick-like fashion. Instead, the nucleobase of one chain is placed opposite the sugar residue of the next chain. As a result, the iodo substituent points towoards the outside of each double chain (composed of $A$ and $B$ chains). The double chains are connected to each other by the $\mathrm{C} 2^{\prime}-\mathrm{H} 2^{\prime} 1 \cdots \mathrm{O} 6^{\text {vi }}$ hydrogen bond. This arrangement can also be visualized by the spacefilling model shown in Fig. 5.

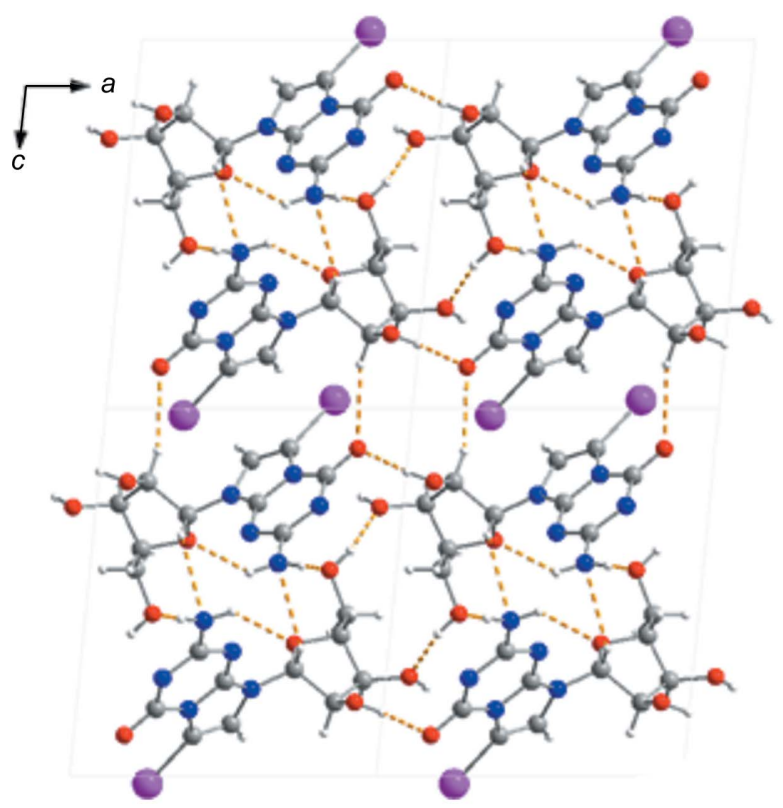

\subsection{Hirshfeld surface analysis of 1}

Hirshfeld surface analysis is a valuable tool to obtain additional insight into the role of crystal packing forces and to visualize the intermolecular interactions of crystalline compounds. The CrystalExplorer program (Version 17; Spackman \& Jayatilaka, 2009; Turner et al., 2017) was used to conduct a Hirshfeld surface analysis mapped over $d_{\text {norm }}(-0.5$ to $1.5 \AA)$, shape index $(-1.0$ to $1.0 \AA$ ) and curvedness $(-4.0$ to $0.4 \AA$ ) (Fig. S2 in the supporting information), as well as a twodimensional (2D) fingerprint plot analysis. The Hirshfeld surface of compound $\mathbf{1}$ is shown in Figs. 6(a) and 6(b). Several red spots are visible on the Hirshfeld surface corresponding to the close $\mathrm{O}-\mathrm{H} \cdots \mathrm{O}$ and $\mathrm{N}-\mathrm{H} \cdots \mathrm{O}$ contacts of the nucleobase and sugar moieties. The shape index indicates $\pi-\pi$ stacking interactions by the presence of adjacent red and blue triangles. Their absence clearly suggests that there are no $\pi-\pi$ interactions in compound 1, as demonstrated by Figs. 6(c) and 6(d).

(a)

A

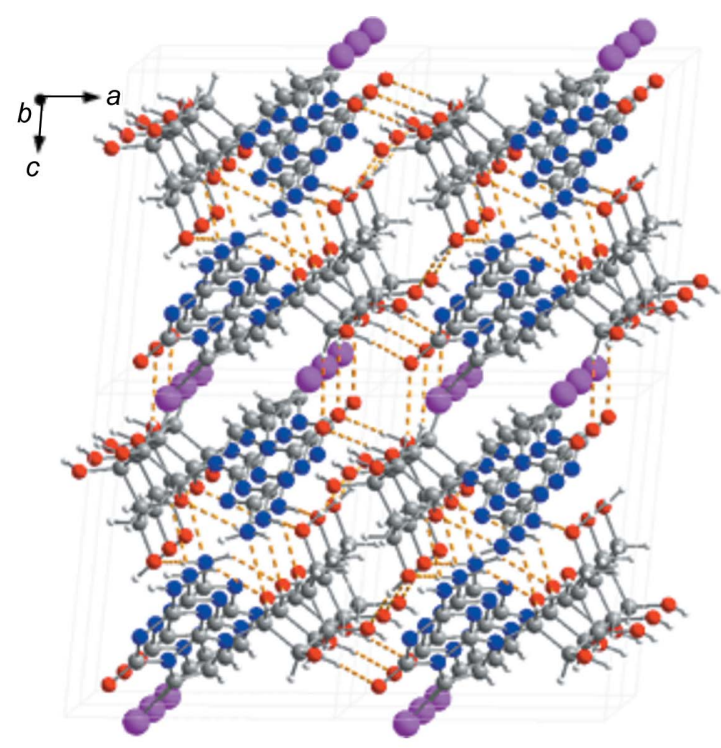

(b)

\section{Figure 4}

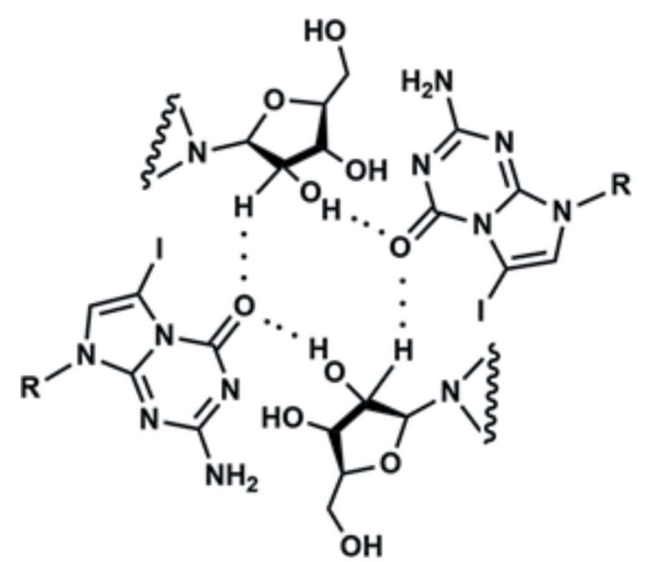

(c)

(a) Hydrogen bonding of $\mathbf{1}$, viewed along the $b$ axis. (b) Multilayered molecular packing of $\mathbf{1}$, shown along the slightly inclined $b$ axis. (c) Detailed view of part $(a)$, showing the nucleobase-sugar interaction forming a central core. 


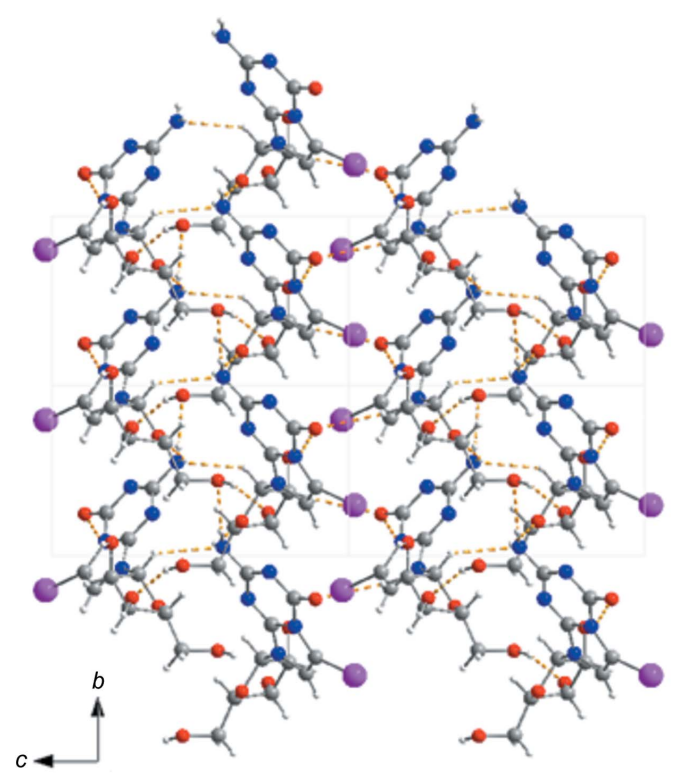

A

B

A

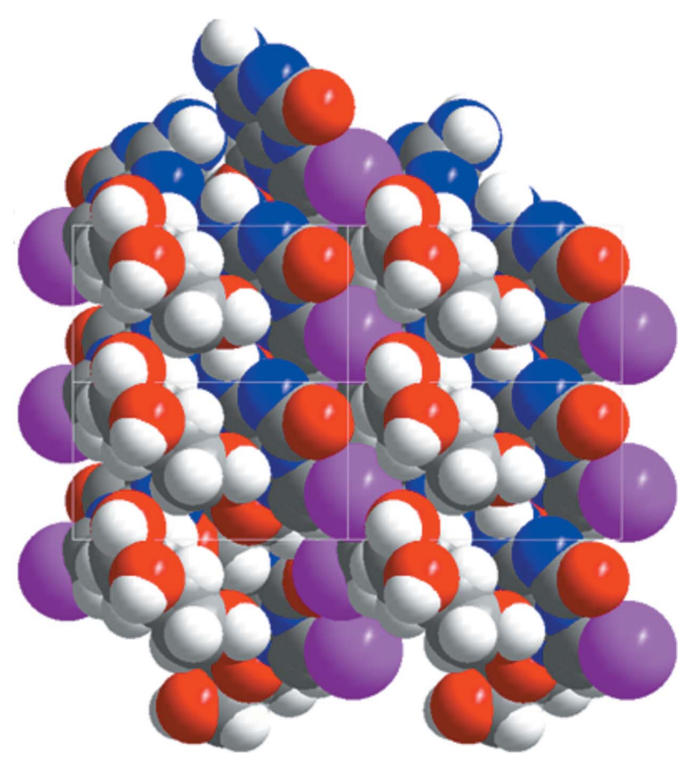

Figure 5

(Top) The crystal packing of $\mathbf{1}$, showing the hydrogen bonds along the $a$ axis. (Bottom) Space-filling model of $\mathbf{1}$, viewed along the $a$ axis.

2D fingerprint plots can be resolved to highlight particular atom pair interactions. This enables the separation of contributions from different contact types that overlap in the full fingerprint plot. The overall 2D fingerprint plot and those resolved into $\mathrm{H} \cdots \mathrm{C} / \mathrm{C} \cdots \mathrm{H}, \mathrm{H} \cdots \mathrm{H}, \mathrm{I} \cdots \mathrm{O} / \mathrm{O} \cdots \mathrm{I}, \mathrm{N} \cdots \mathrm{H} /$ $\mathrm{H} \cdots \mathrm{N}$ and $\mathrm{O} \cdots \mathrm{H} / \mathrm{H} \cdots \mathrm{O}$ contacts are illustrated in Fig. 7, together with their relative contributions to the Hirshfeld surface. The proportions of $\mathrm{O} \cdots \mathrm{H} / \mathrm{H} \cdots \mathrm{O}, \mathrm{H} \cdots \mathrm{H}$ and $\mathrm{N} \cdots \mathrm{H} /$ $\mathrm{H} \cdots \mathrm{N}$ interactions comprise 28.7, 19.1 and $15.9 \%$, respectively, of the total Hirshfeld surfaces. Lower percentages are found for the $\mathrm{H} \cdots \mathrm{C} / \mathrm{C} \cdots \mathrm{H}$ contacts $(9.2 \%)$. Moreover, the interaction between iodo substituent $\mathrm{I} 7$ and atom $\mathrm{O}_{2}^{\prime}$ is confirmed and appears as two wings in the fingerprint plot, with a proportion of $4.1 \%$.
3.4. The stability of 5-aza-7-deazaguanine base pairs controlled by $\mathrm{p} K$ value differences of complementary bases

The Watson-Crick base-pair recognition of canonical DNA and RNA constituents depends on the hydrogen-bonding donor-acceptor pattern of purine and pyrimidine nucleosides, as well as on environmental influences caused by base-to-base stacking interactions, helix formation and various other factors. Among these, the $\mathrm{p} K$ values of nucleobases play an important role as they control the stability and lifetime of base pairs. Recently, the role of the $\mathrm{p} K$ values of nucleobases has been discussed with regard to the origin of chemical evolution. Strong base pairs are formed when the $\mathrm{p} K$ value difference $(\Delta \mathrm{p} K)$ between the acceptor and donor sites of nucleobases is at least five units or more. A $\Delta \mathrm{p} K<5$ results in weaker base pairs (Krishnamurthy, 2012).

Early studies on the physical properties of 5-aza-7-deaza- $2^{\prime}$ deoxyguanosine (2b) showed that the nucleobase is protonated on the $s$-triazine moiety having a $\mathrm{p} K_{a}$ value of 3.7 (Rosemeyer \& Seela, 1987). Nitrogen-1 was established as the protonation site using ${ }^{13} \mathrm{C}$ NMR spectroscopy (Seela \& Melenewski, 1999). The $\mathrm{p} K_{a}$ value and the protonation site is different from the closely related $2^{\prime}$-deoxyguanosine $\left(\mathrm{p} K_{a}\right.$ value of protonation $=1.6$ and deprotonation $=9.2)($ Seela $e t$ al., 2003), as well as to 7-deaza-2'-deoxyguanosine (1.1 and 10.3) (Ramzaeva \& Seela, 1996), and is a direct consequence of the transposition of the nitrogen-7 atom to bridgehead position-5.

The positional change of the $\mathrm{N}$ atom leads to the absence of a proton at $\mathrm{N} 1$ which now becomes a proton-acceptor site and not a donor site as in $2^{\prime}$-deoxyguanosine or 7-deaza- $2^{\prime}$-deoxyguanosine. Furthermore, position-7 cannot interact with protons or metal ions anymore, and similar to 7-deaza- 2 '-deoxyguanosine, Hoogsteen base pairs cannot be formed.
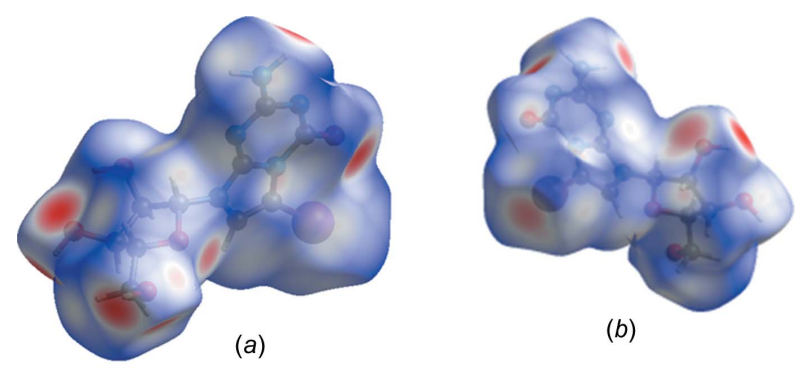

(b)
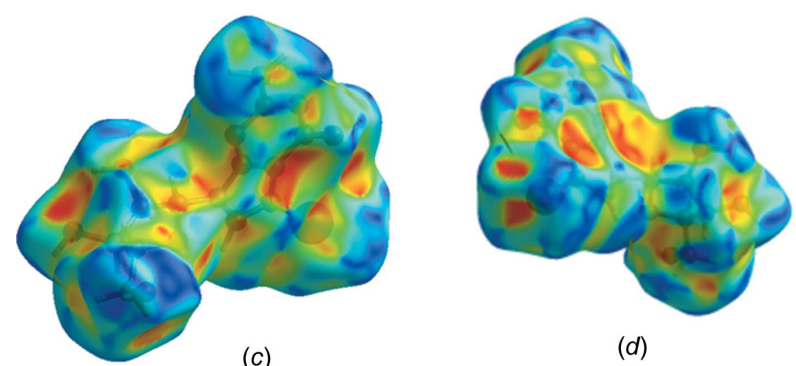

(d)

Figure 6

Hirshfeld surface of compound $\mathbf{1}$, mapped over $d_{\text {norm }}(-0.5$ to $1.5 \AA$ ), shown in $(a)$ a front and $(b)$ a back view. The shape index, shown in $(c)$ a front and $(d)$ a back view. 
Consequently, 5-aza-7-deaza-2'-deoxyguanosine exhibits a Watson-Crick recognition face similar to that of isocytidine. Thus, the complementary base has to provide a proton, as observed for base pairing with guanine or isoguanine, or with protonated cytidines or cytidine derivatives which carry a proton at nitrogen-1 (Fig. 8a) (Hoshika et al., 2018). Silver ions can function as proton substitutes forming metal-mediated base pairs (Fig. 8b) (Guo et al., 2018).

As ribonucleoside $\mathbf{1}$ is a promising candidate for the synthesis of 'all-purine' RNA, it is of particular importance to identify the $\mathrm{p} K_{a}$ value of $\mathbf{1}$ and to compare this value to related purine and 7-deazapurine nucleosides. The $\mathrm{p} K_{a}$ value of compound $\mathbf{1}$ was determined by UV spectroscopic titration from absorbance changes at $280 \mathrm{~nm}$ at different $\mathrm{pH}$ values (Fig. S3 in the supporting information). According to Fig. 9, the $\mathrm{p} K_{a}$ value of $\mathbf{1}$ is 3.6. This $\mathrm{p} K_{a}$ value is almost identical to that of the corresponding $2^{\prime}$-deoxyribonucleoside $2 \mathrm{c}\left(\mathrm{p} K_{a}=\right.$ 3.7) (Lin et al., 2004) and the purine nucleoside adenosine $\left(\mathrm{p} K_{a}=3.6\right)$. Contrary to the related purine and 7-deazapurine nucleosides, the molecule does not show a second $\mathrm{p} K$ value (for deprotonation), as the heterocyclic skeleton does not carry a proton which can be released in alkaline medium. Atom N1 is the protonation site, as was determined for 5-aza7-deazaguanine 2'-deoxyribonucleoside 2 b (Seela \& Melenewski, 1999).

Table S3 (see supporting information) summarizes the $\mathrm{p} K$ values and protonation positions for 5-aza-7-deazaguanine,

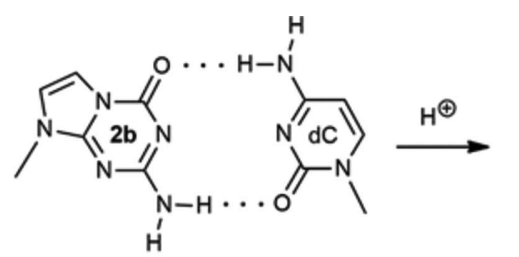<smiles></smiles>

(a)<smiles>Cn1ccc(NCOc2nc(NC=O)nc3nccn23)n1</smiles>

silver-mediated base pair

(b)

Figure 8

(a) Protonated base pair of 5-aza-7-deaza-2'-deoxyguanosine (2b) and $2^{\prime}$-deoxycytidine formed in acidic medium. (b) Silver-mediated base pair of $\mathbf{2} \mathbf{b}$ and $\mathrm{dC}$.

7-deazaguanine, guanine and isoguanine nucleosides. It is obvious that the iodo substituent has no significant influence on the $\mathrm{p} K$ value of the nucleosides. However, compared to guanosine and 7-deazaguanosine, the $\mathrm{p} K$ for protonation of the unsubstituted and iodinated 5-aza-7-deazaguanosine base is strongly shifted and the molecule is much easier to protonate. Also, the position of protonation (N1) is different from that in guanosine (N7) and 7-deazaguanosine (N3).
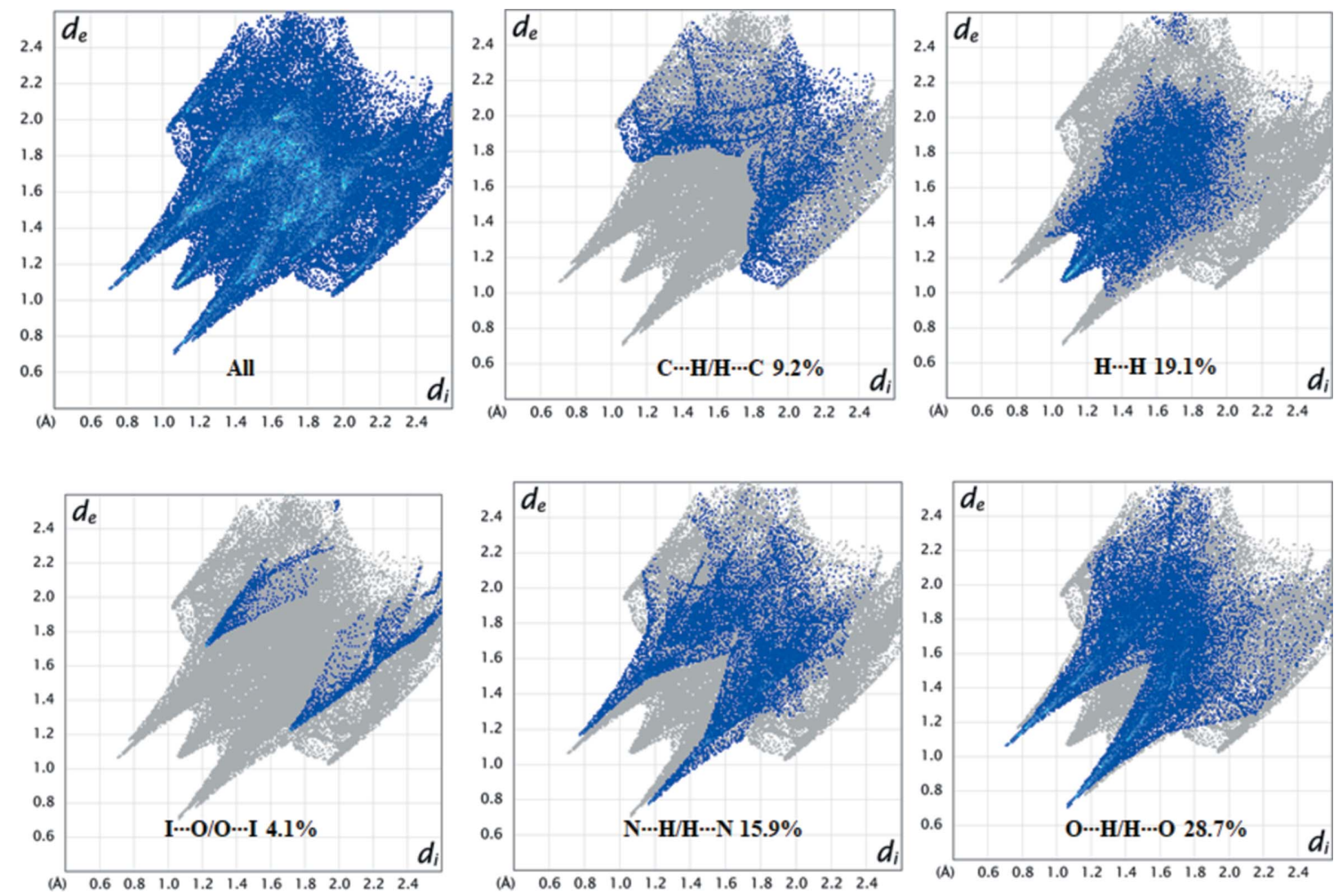

Figure 7

2D fingerprint plots showing the percentages of the contribution of various interactions to the total Hirshfeld surface area of compound 1. Full interactions (upper row, left) and resolved contacts (upper row: middle, $\mathrm{C} \cdots \mathrm{H} / \mathrm{H} \cdots \mathrm{C}$; right, $\mathrm{H} \cdots \mathrm{H}$; lower row: left, I $\cdots \mathrm{O} / \mathrm{O} \cdots \mathrm{I} ; \mathrm{middle}, \mathrm{N} \cdots \mathrm{H} / \mathrm{H} \cdots \mathrm{N}$; right, $\mathrm{O} \cdots \mathrm{H} / \mathrm{H} \cdots \mathrm{O})$. 


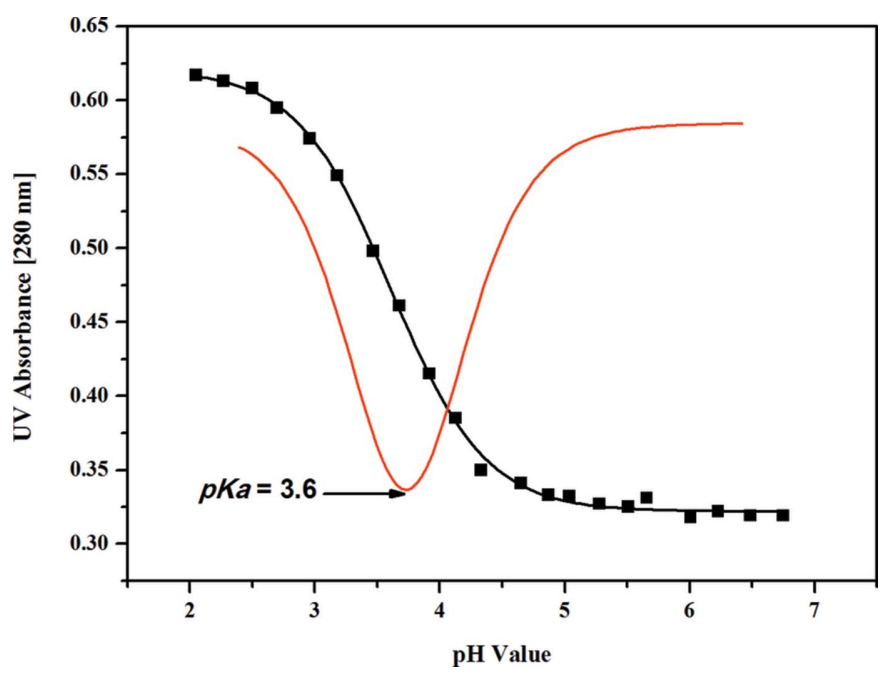

Figure 9

$\mathrm{p} K_{a}$ value of $\mathbf{1}$ determined by UV titration (1st derivative, red line). Spectroscopic changes determined at $280 \mathrm{~nm}$ at different $\mathrm{pH}$ values (black line) were measured in $0.1 M$ sodium phosphate buffer.

It has been shown that based on $\mathrm{p} K$ value differences of nucleosides participating in base-pair formation, predictions regarding base-pair stability can be made (Krishnamurthy, 2012). To this end, the $\Delta \mathrm{p} K$ of base pairs of 7-iodo-5-aza-7deazaguanosine with different nucleosides acting as donor or acceptor were calculated and compared (Fig. 10). Antiparallel (aps) and parallel (ps) strand orientation of oligonucleotides within a duplex were considered.

The $\Delta \mathrm{p} K$ of the 7-iodo-5-aza-7-deazaguanosine-isoguanosine base pair is 6.2 (motif I, Fig. 10) referring to an aps orientation of oligonucleotides. As a result, the stability of this purine-purine base pair is expected to be higher than for the Watson-Crick purine-pyrimidine $\mathrm{G}-\mathrm{C}$ base pair $(\Delta \mathrm{p} K=4.8$; motif VII, Fig. 10). A parallel arrangement of 1 with guanosine ( $\Delta \mathrm{p} K=5.7$; motif II) or 7-deazaguanosine $(\Delta \mathrm{p} K=6.6$; motif III) also leads to stable purine-purine pairs. However, the formation of a purine-pyrimidine base pair with $\mathbf{1}$ results in a mismatch situation in an aps alignment with cytidine $(\Delta \mathrm{p} K=$ 0.9 ; motif IV) or isocytidine $(\Delta \mathrm{p} K=0.7$; motif VI). Consequently, the RNA constituent $\mathbf{1}$ is a promising candidate for the construction of stable purine-purine base pairs as building blocks for 'all-purine' RNA with a conventional antiparallel orientation of the strands. Moreover, even a parallel orientation of oligonucleotides might be applicable. The 7-iodo substituent allows the introduction of reporter groups to

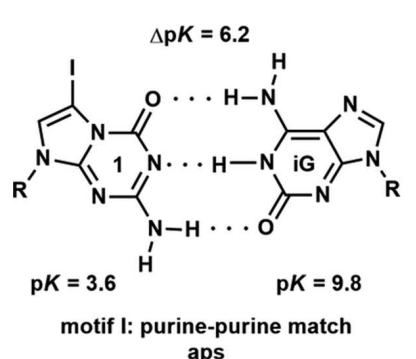

aps

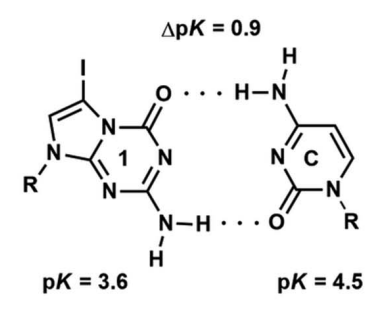

motif IV: purine-pyrimidine mismatch aps

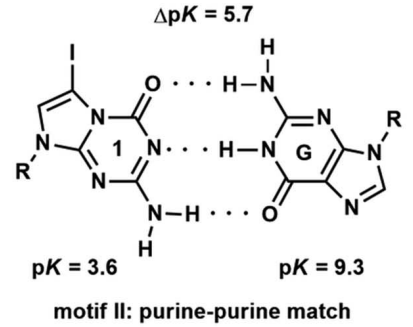

ps

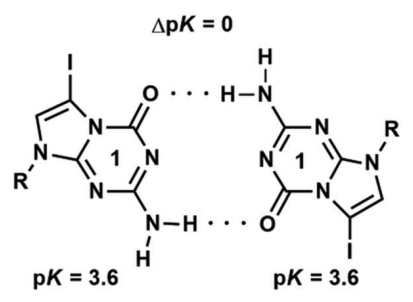

motif V: purine-purine mismatch ps

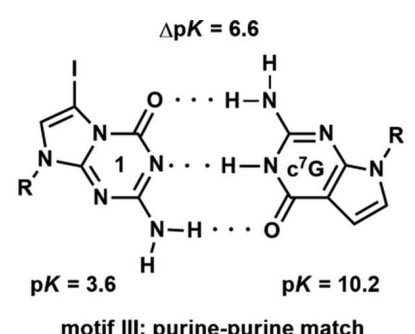

ps

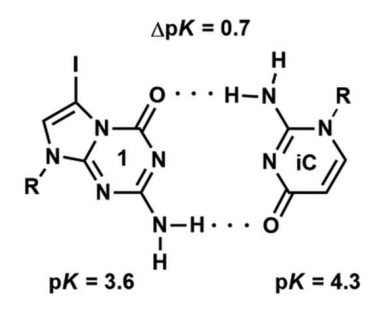

motif VI: purine-pyrimidine mismatch

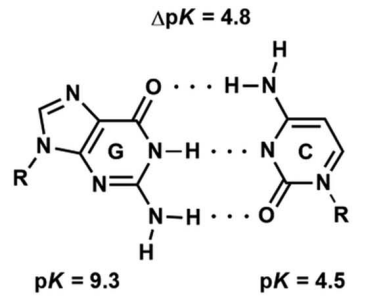

motif VII: purine-pyrimidine match

Figure 10

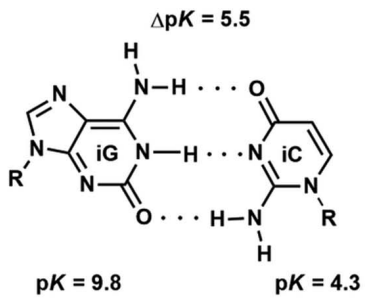

motif VIII: purine-pyrimidine match

aps

Base-pairing motifs of 5-aza-7-deazaguanine nucleosides, $\mathrm{p} K_{a}$ values of the base-pairing nucleosides and their $\mathrm{p} K$ value difference $(\Delta \mathrm{p} K)$, as well as strand orientation of the respective duplex. Notes: $\mathrm{R}=\beta$-D-ribofuranosyl, $\mathrm{C}=$ cytidine, $\mathrm{iG}=$ isoguanosine, $\mathrm{iC}=\mathrm{isocytidine}, \mathrm{G}=\mathrm{guanosine}, \mathrm{c}^{7} \mathrm{G}=$ 7-deazaguanosine, aps = antiparallel strands and $\mathrm{ps}=$ parallel strands. 
research papers

monitor structural characteristics of aps or ps 'all-purine' RNA.

However, self-pairing of $\mathbf{1}$, as demonstrated by motif V (ps alignment; Fig. 10) or even in a shifted arrangement, leads to a mismatch situation. Moreover, none of the reported crystal structures of 5-aza-7-deazaguanine nucleosides show selfpairing of the nucleobases (Kojić-Prodić et al., 1982; Seela et al., 2002; Leonard et al., 2019). Only for the isolated 5-aza-7deazaguanine nucleobase was self-pairing observed when one of the nucleobases forms a N3-H tautomer (Laos et al., 2019). In nucleosides, as well as in nucleic acids, this arrangement is not possible as the ribose moiety is attached to $\mathrm{N} 9$ and the N3 atom lacks a proton.

\subsection{Functionalization of nucleoside 1 and fluorescence properties of the conjugate 3}

The ability of 7-iodoribonucleoside $\mathbf{1}$ to act as a target for functionalization with functional reporter groups is demonstrated by use of the Suzuki-Miyaura cross-coupling reaction (Agrofoglio et al., 2003). As the benzofuran residue is sensitive to molecular crowding and the viscosity of solvents (Greco \& Tor, 2007; Leonard et al., 2019), this residue was chosen for functionalization of ribonucleoside $\mathbf{1}$.

For this, compound $\mathbf{1}$ was used as the starting material (see Scheme 1). The synthesis of ribonucleoside $\mathbf{1}$ by nucleobase anion glycosylation was reported recently, employing isobutyrylated iodo base 4 and bromo sugar 5 (Leonard et al., 2019). In order to introduce the benzofuran side chain, SuzukiMiyaura cross-coupling of ribonucleoside $\mathbf{1}$ and benzofuran-2boronic acid was performed. The reaction was carried out under reflux for $30 \mathrm{~min}$ in a $\mathrm{CH}_{3} \mathrm{CN} / \mathrm{H}_{2} \mathrm{O}$ mixture $(1: 1 \mathrm{v} / \mathrm{v})$ in the presence of $\mathrm{Pd}\left(\mathrm{PPh}_{3}\right)_{4}$ and $\mathrm{Na}_{2} \mathrm{CO}_{3} \cdot \mathrm{H}_{2} \mathrm{O}$ (see Scheme 1), yielding benzofuran derivative 3 in $57 \%$.

The new compound 3 was characterized by ${ }^{1} \mathrm{H}$ and ${ }^{13} \mathrm{C}$ NMR spectroscopy, as well as by ESI-TOF mass spectroscopy. ${ }^{1} \mathrm{H}-{ }^{13} \mathrm{C}$ correlated (HMBC and HSQC) NMR spectra were used to assign the ${ }^{13} \mathrm{C}$ NMR signals (for spectra, see the supporting information, and for details, see the Experimental section).

The UV and fluorescence spectra of $\mathbf{3}$ were recorded in solvents of different polarity, and the corresponding Stokes shift and quantum yields were determined (Table S4 in the supporting information). The UV spectra of compound $\mathbf{3}$ show two maxima at around 312 and $327 \mathrm{~nm}$ in $\mathrm{MeOH}, \mathrm{MeCN}$ and water (Fig. S4 in the supporting information). The maxima are bathochromally shifted (around $5 \mathrm{~nm}$ ) in the less polar solvents dimethyl sulfoxide (DMSO) and dimethylformamide (DMF).

The fluorescence emission spectra for benzofuran conjugate 3 in various solvents are displayed in Fig. 11(a). The highest quantum yields are obtained in DMF and DMSO (Table S4 in the supporting information), with emission maxima which are red-shifted compared to the other solvents. The fluorescence of $\mathbf{3}$ is very low in water compared to the other polar solvents.

In the RNA constituent $\mathbf{3}$, the benzofuran moiety and the 5-aza-7-deazaguanine base are separated by a freely rotatable

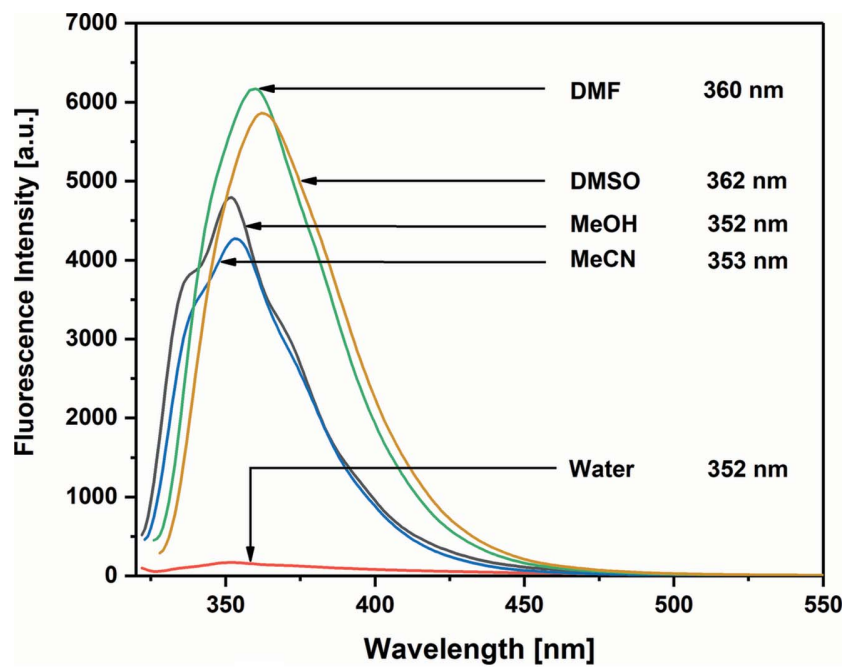

(a)

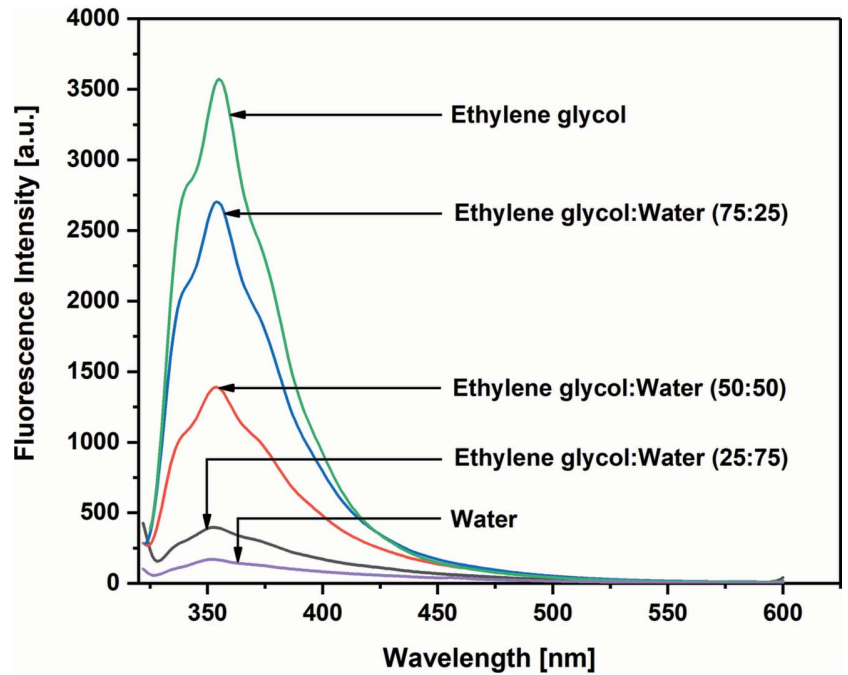

(b)

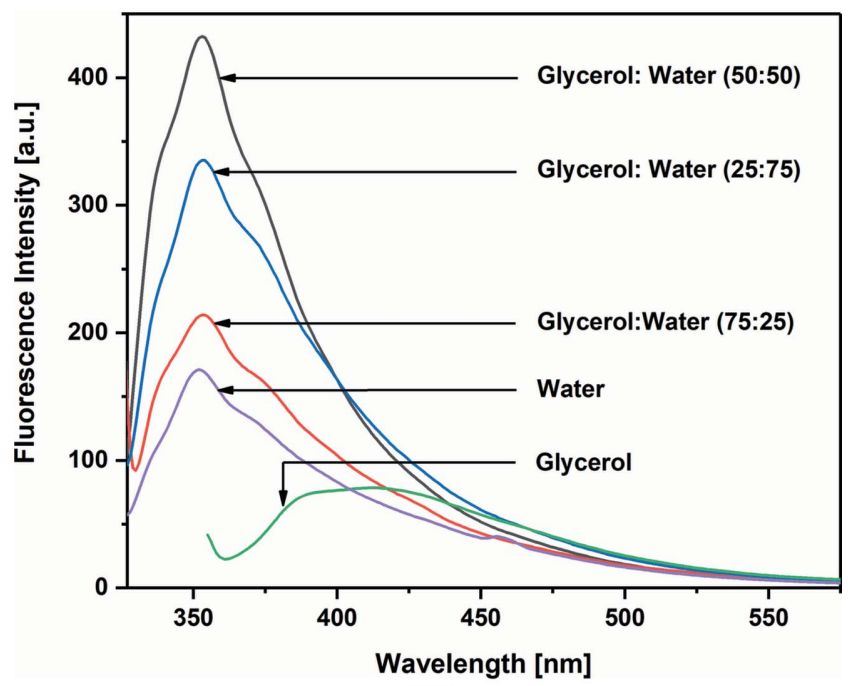

(c)

Figure 11

Fluorescence emission spectra of compound $\mathbf{3}(1 \mu M)$ measured in $(a)$ solvents of different polarity, $(b)$ ethylene glycol and (c) glycerol. Excitation wavelength of nucleoside 3 was $315 \mathrm{~nm}$ in ethylene glycol and $345 \mathrm{~nm}$ in glycerol. 
aryl-aryl bond. The spatial positioning of both aromatic systems with respect to each other ( $\pi-\pi$ conjugation) has a direct impact on the fluorescence properties of conjugate 3 . In order to study this effect for $\mathbf{3}$, fluorescence measurements were performed in solvents of similar polarity but different viscosity. Fig. 11(b) shows the fluorescence emission spectra of conjugate 3 determined in ethylene glycol, water and their mixtures. The fluorescence of $\mathbf{3}$ is highest in ethylene glycol and decreases with reduced viscosity of ethylene glycol/water mixtures. However, the highest fluorescence is observed in a $50 \%$ glycerol-water mixture (Fig. 11c). Apparently, a rotational barrier exists for the benzofuran residue which is sensitive to solvent viscosity, a phenomenon which has been reported for other nucleoside-benzofuran conjugates (Tanpure \& Srivatsan, 2018; Tokugawa et al., 2016; Manna et al., 2018).

\section{Conclusion and outlook}

The single-crystal X-ray structure of 7-iodo-5-aza-7-deazaguanosine (1) was determined and the geometric parameters of this RNA constituent were analyzed. This includes an anti conformation of the 5-aza-7-deazaguanine base, an $N$ conformation ( $\mathrm{O}^{\prime}$-endo) of the ribose moiety and an antiperiplanar orientation of the $5^{\prime}$-hydroxy group.

The crystal packing is controlled by interactions between the nucleobase and sugar moieties, while self-pairing of the
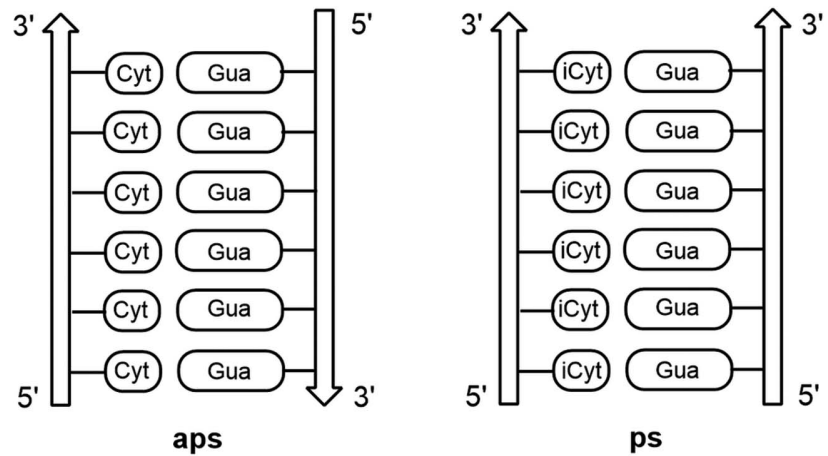

Watson-Crick RNA

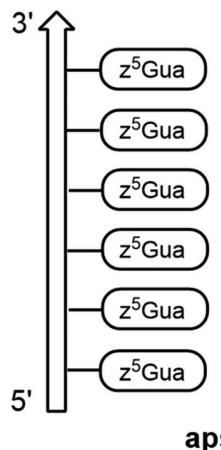

aps

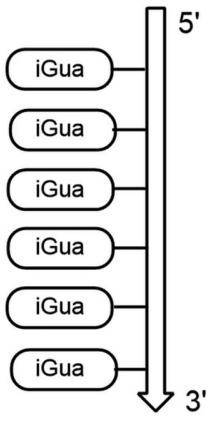

"all-purine" RNA

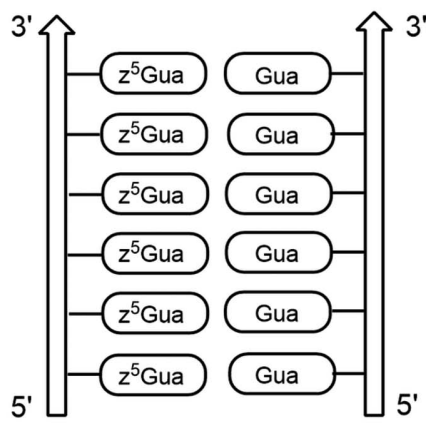

ps
Figure 12

Illustration of RNA duplexes with pyrimidine-purine and purine-purine pairs with $(a) /(c)$ antiparallel-stranded (aps) and $(b) /(d)$ parallel-stranded (ps) orientations. Notes: Cyt $=$ cytosine, Gua $=$ guanine, iCyt $=$ isocytosine, $\mathrm{z}^{5} \mathrm{Gua}=5$-aza-7-deazaguanine and iGua $=$ isoguanine. nucleobase does not take place. The 7-iodo substituent forms a contact to oxygen-O2' of the ribofuranosyl moiety. A Hirshfeld surface analysis of $\mathbf{1}$ highlights the contacts of the nucleobase and sugar moieties $(\mathrm{O}-\mathrm{H} \cdots \mathrm{O}$ and $\mathrm{N}-\mathrm{H} \cdots \mathrm{O})$. The concept of $\mathrm{p} K$ value differences was applied to predict base pairing of $\mathbf{1}$. Ribonucleoside $\mathbf{1}$ has the ability to form extraordinary stable antiparallel-stranded purine-purine pairs with isoguanosine or base pairs with guanosine displaying a parallel-strand arrangement. Related base pairs were described for 'all-purine' DNA (Seela et al., 2001).

Due to the large surface area of purine-purine pairs, base stacking in 'all-purine' RNA is expected to be stronger, as in canonical RNA formed by pyrimidine-purine pairs (Figs. 12a and $12 b$ ). Furthermore, it was shown that the 7-iodo substituent of ribonucleoside $\mathbf{1}$ could be functionalized. Benzofuran was used in this work to detect restrictions of rotational motion by fluorescence spectroscopy.

\section{Acknowledgements}

We thank Dr Peter Leonard for a critical reading of the manuscript. We would like to thank Dr Letzel, OrganischChemisches Institut, Universität Münster, Germany, for the measurement of the mass spectra and Professor Dr B. Wünsch, Institut für Pharmazeutische und Medizinische Chemie, Universität Münster, for providing us with $600 \mathrm{MHz}$ NMR spectra. Funding by ChemBiotech, Münster, Germany, is gratefully acknowledged.

\section{References}

Agrofoglio, L. A., Gillaizeau, I. \& Saito, Y. (2003). Chem. Rev. 103, 1875-1916.

Altona, C. \& Sundaralingam, M. (1972). J. Am. Chem. Soc. 94, 82058212.

Blackburn, G. M., Gait, M. J., Loakes, D. \& Williams, D. M. (2006). Editors. Nucleic Acids in Chemistry and Biology, 3rd ed. Cambridge: RSC Publishing.

Bruker (1998). XP. Version 5.1. Bruker AXS Inc., Madison, Wisconsin, USA.

Bruker (2014). SADABS. Bruker AXS Inc., Madison, Wisconsin, USA.

Bruker (2015). SAINT. Bruker AXS Inc., Madison, Wisconsin, USA. Bruker (2016). APEX3. Bruker AXS Inc., Madison, Wisconsin, USA. Greco, N. J. \& Tor, Y. (2007). Tetrahedron, 63, 3515-3527.

Guo, X., Leonard, P., Ingale, S. A., Liu, J., Mei, H., Sieg, M. \& Seela, F. (2018). Chem. Eur. J. 24, 8883-8892.

Hoshika, S., Singh, I., Switzer, C., Molt, R. W. Jr, Leal, N. A., Kim, M.-J., Kim, M.-S., Kim, H.-J., Georgiadis, M. M. \& Benner, S. A. (2018). J. Am. Chem. Soc. 140, 11655-11660.

IUPAC-IUB Joint Commission on Biochemical Nomenclature (1983). Eur. J. Biochem. 131, 9-15.

Kojić-Prodić, B., Ružić-Toroš, Ž., Golič, L., Brdar, B. \& Kobe, J. (1982). Biochim. Biophys. Acta, 698, 105-110.

Krishnamurthy, R. (2012). Acc. Chem. Res. 45, 2035-2044.

Laos, R., Lampropoulos, C. \& Benner, S. A. (2019). Acta Cryst. C75, 22-28.

Leonard, P. (2020). Personal communication.

Leonard, P., Kondhare, D., Jentgens, X., Daniliuc, C. \& Seela, F. (2019). J. Org. Chem. 84, 13313-13328.

Lin, W., Zhang, X. \& Seela, F. (2004). Helv. Chim. Acta, 87, 22352244. 
Manna, S., Sarkar, D. \& Srivatsan, S. G. (2018). J. Am. Chem. Soc. 140, 12622-12633.

Müller, S. L., Zhou, X., Leonard, P., Korzhenko, O., Daniliuc, C. \& Seela, F. (2019). Chem. Eur. J. 25, 3077-3090.

Parsons, S., Flack, H. D. \& Wagner, T. (2013). Acta Cryst. B69, 249259.

Ramzaeva, N. \& Seela, F. (1996). Helv. Chim. Acta, 79, 1549-1558.

Rosemeyer, H. \& Seela, F. (1987). J. Org. Chem. 52, 5136-5143.

Saenger, W. (1984). In Principles of Nucleic Acid Structure, edited by C. R. Cantor. New York: Springer-Verlag.

Seela, F., Amberg, S., Melenewski, A. \& Rosemeyer, H. (2001). Helv. Chim. Acta, 84, 1996-2014.

Seela, F. \& Melenewski, A. (1999). Eur. J. Org. Chem. 1999, 485496.

Seela, F., Melenewski, A. \& Wei, C. (1997). Bioorg. Med. Chem. Lett. 7, 2173-2176.

Seela, F., Ramzaeva, N. \& Rosemeyer, H. (2003). Science of Synthesis, Vol. 16, edited by Y. Yamamoto, pp. 945-1108. Stuttgart: Georg Thieme Verlag.

Seela, F. \& Rosemeyer, H. (2002). Recent Advances in Nucleosides: Chemistry and Chemotherapy, edited by C. K. Chu, pp. 505-533. Amsterdam: Elsevier.
Seela, F., Rosemeyer, H., Melenewski, A., Heithoff, E.-M., Eickmeier, H. \& Reuter, H. (2002). Acta Cryst. C58, o142-o144.

Sheldrick, G. M. (2015a). Acta Cryst. A71, 3-8.

Sheldrick, G. M. (2015b). Acta Cryst. C71, 3-8.

Spackman, M. A. \& Jayatilaka, D. (2009). CrystEngComm, 11, 19-32.

Tanpure, A. A. \& Srivatsan, S. G. (2018). ChemBioChem, 13, 2392 2399.

Tokugawa, M., Masaki, Y., Canggadibrata, J. C., Kaneko, K., Shiozawa, T., Kanamori, T., Grøtli, M., Wilhelmsson, L. M., Sekine, M. \& Seio, K. (2016). Chem. Commun. 52, 3809-3812.

Turner, M. J., McKinnon, J. J., Wolff, S. K., Grimwood, D. J., Spackman, P. R., Jayatilaka, D. \& Spackman, M. A. (2017). CrystalExplorer17. University of Western Australia. http://hirshfeldsurface.net.

Van Wijk, L., Haasnoot, C. A. G., de Leeuw, F. A. A. M., Huckriede, B. D., Westra Hoekzema, A. J. A. \& Altona, C. (1999). PSEUROT6.3. Leiden Institute of Chemistry, Leiden University, The Netherlands.

Wächtershäuser, G. (1988). Proc. Natl Acad. Sci. USA, 85, 1134-1135.

Watson, J. D. \& Crick, F. H. (1953). Nature, 171, 737-738.

Winnacker, M. \& Kool, E. T. (2013). Angew. Chem. Int. Ed. 52, 12498-12508. 


\section{supporting information}

Acta Cryst. (2020). C76, 513-523 [https://doi.org/10.1107/S2053229620004684]

\section{7-Iodo-5-aza-7-deazaguanine ribonucleoside: crystal structure, physical} properties, base-pair stability and functionalization

\section{Dasharath Kondhare, Simone Budow-Busse, Constantin Daniliuc and Frank Seela}

Computing details

Data collection: APEX3 (Bruker, 2016); cell refinement: SAINT (Bruker, 2015); data reduction: SAINT (Bruker, 2015); program(s) used to solve structure: SHELXT2014 (Sheldrick, 2015a); program(s) used to refine structure: SHELXL2014 (Sheldrick, 2015b); molecular graphics: APEX3 (Bruker, 2016) and XP (Bruker, 1998); software used to prepare material for publication: APEX3 (Bruker, 2016).

7-lodo-5-aza-7-deazaguanosine

\section{Crystal data}

$\mathrm{C}_{10} \mathrm{H}_{12} \mathrm{IN}_{5} \mathrm{O}_{5}$

$M_{r}=409.15$

Monoclinic, $P 2_{1}$

$a=9.1086(2) \AA$

$b=6.3149(2) \AA$

$c=11.0428(3) \AA$

$\beta=95.585(1)^{\circ}$

$V=632.17(3) \AA^{3}$

$Z=2$

\section{Data collection}

Kappa CCD APEXII diffractometer

Radiation source: fine-focus sealed tube, finefocus sealed tube

Graphite monochromator

Detector resolution: 8.3333 pixels $\mathrm{mm}^{-1}$

phi $/ \omega$ scans

Absorption correction: multi-scan

(SADABS; Bruker, 2014)

\section{Refinement}

Refinement on $F^{2}$

Least-squares matrix: full

$R\left[F^{2}>2 \sigma\left(F^{2}\right)\right]=0.036$

$w R\left(F^{2}\right)=0.097$

$S=1.07$

2216 reflections

205 parameters

12 restraints

Hydrogen site location: mixed
$F(000)=400$

$D_{\mathrm{x}}=2.149 \mathrm{Mg} \mathrm{m}^{-3}$

$\mathrm{Cu} K \alpha$ radiation, $\lambda=1.54178 \AA$

Cell parameters from 9825 reflections

$\theta=4.0-66.8^{\circ}$

$\mu=20.25 \mathrm{~mm}^{-1}$

$T=100 \mathrm{~K}$

Needle, colourless

$0.35 \times 0.06 \times 0.02 \mathrm{~mm}$

$T_{\min }=0.39, T_{\max }=0.69$

15087 measured reflections

2216 independent reflections

2144 reflections with $I>2 \sigma(I)$

$R_{\text {int }}=0.072$

$\theta_{\text {max }}=66.9^{\circ}, \theta_{\text {min }}=4.0^{\circ}$

$h=-10 \rightarrow 10$

$k=-7 \rightarrow 7$

$l=-13 \rightarrow 13$

$\mathrm{H}$ atoms treated by a mixture of independent and constrained refinement

$w=1 /\left[\sigma^{2}\left(F_{\mathrm{o}}{ }^{2}\right)+(0.069 P)^{2}\right]$

where $P=\left(F_{\mathrm{o}}{ }^{2}+2 F_{\mathrm{c}}{ }^{2}\right) / 3$

$(\Delta / \sigma)_{\max }=0.001$

$\Delta \rho_{\max }=2.79 \mathrm{e} \AA^{-3}$

$\Delta \rho_{\text {min }}=-1.19$ e $\AA^{-3}$ 
Absolute structure: Flack $x$ determined using 919 quotients $[(\mathrm{I}+)-(\mathrm{I}-)] /[(\mathrm{I}+)+(\mathrm{I}-)]$ (Parsons et al., 2013)

Absolute structure parameter: 0.040 (7)

\section{Special details}

Geometry. All e.s.d.'s (except the e.s.d. in the dihedral angle between two 1.s. planes) are estimated using the full covariance matrix. The cell e.s.d.'s are taken into account individually in the estimation of e.s.d.'s in distances, angles and torsion angles; correlations between e.s.d.'s in cell parameters are only used when they are defined by crystal symmetry. An approximate (isotropic) treatment of cell e.s.d.'s is used for estimating e.s.d.'s involving l.s. planes.

Refinement. Reflections were merged by SHELXL according to the crystal class for the calculation of statistics and refinement.

_reflns_Friedel_fraction is defined as the number of unique Friedel pairs measured divided by the number that would be possible theoretically, ignoring centric projections and systematic absences.

The $\mathrm{H}$ atoms at $\mathrm{N}^{\prime}, \mathrm{O}^{\prime}, \mathrm{O}^{\prime}$ and $\mathrm{O}^{\prime}$ atoms were refined freely, but with $\mathrm{N}-\mathrm{H}$ and $\mathrm{O}-\mathrm{H}$ distance restraints $(D F I X$ and U-fixed value). For atom $\mathrm{Cl}^{\prime}$ the ISOR 0.002 command was used in order to hold this atom positive definite.

Data sets for compound 1 were collected with a Bruker Kappa APEXII CCD diffractometer. Programs used: data collection: APEX3 V2016.1-0 (Bruker, 2016); cell refinement: SAINT V8.37 A (Bruker, 2015); data reduction: SAINT V8.37 A (Bruker, 2015); absorption correction, SADABS V2014/7 (Bruker, 2014); structure solution SHELXT-2015 (Sheldrick, 2015a); structure refinement SHELXL-2015 (Sheldrick, 2015b) and graphics, XP (Version 5.1, Bruker, 1998). $R$-values are given for observed reflections, and $w R_{2}$ values are given for all reflections.

Fractional atomic coordinates and isotropic or equivalent isotropic displacement parameters $\left(\AA^{2}\right)$

\begin{tabular}{|c|c|c|c|c|}
\hline & $x$ & $y$ & $z$ & $U_{\text {iso }} * / U_{\text {eq }}$ \\
\hline I7 & 0.74360 & $0.29931(18)$ & -0.02110 & $0.0130(2)$ \\
\hline N1 & $0.7285(9)$ & $0.9079(15)$ & $0.2659(8)$ & $0.0143(18)$ \\
\hline $\mathrm{N} 2$ & $0.6126(9)$ & $1.0539(14)$ & $0.4220(8)$ & $0.0163(18)$ \\
\hline $\mathrm{H} 2 \mathrm{~A}$ & $0.522(7)$ & $1.07(2)$ & $0.447(12)$ & $0.024 *$ \\
\hline $\mathrm{H} 2 \mathrm{~B}$ & $0.683(11)$ & $1.154(16)$ & $0.426(13)$ & $0.024^{*}$ \\
\hline N3 & $0.5101(9)$ & $0.7501(12)$ & $0.3384(8)$ & $0.015(2)$ \\
\hline N5 & $0.6333(8)$ & $0.5881(12)$ & $0.1806(7)$ & $0.0099(16)$ \\
\hline N9 & $0.4366(8)$ & $0.4278(13)$ & $0.2366(7)$ & $0.0110(16)$ \\
\hline O6 & 0.8350 & $0.7477(10)$ & $0.1110(6)$ & $0.0154(18)$ \\
\hline $\mathrm{O} 2^{\prime}$ & $0.0943(7)$ & $0.5796(12)$ & $0.2008(7)$ & $0.0179(15)$ \\
\hline $\mathrm{H} 2^{\prime}$ & $0.001(5)$ & $0.58(2)$ & $0.173(12)$ & $0.027^{*}$ \\
\hline O3' & $-0.0751(7)$ & $0.2555(10)$ & $0.2699(6)$ & $0.0156(18)$ \\
\hline H3' & $-0.138(11)$ & $0.158(15)$ & $0.244(12)$ & $0.023^{*}$ \\
\hline $\mathrm{O} 4^{\prime}$ & $0.3093(7)$ & $0.2052(11)$ & $0.3593(7)$ & $0.0135(14)$ \\
\hline $\mathrm{O} 5^{\prime}$ & $0.2182(8)$ & $-0.0556(13)$ & $0.5595(7)$ & $0.0197(16)$ \\
\hline $\mathrm{H} 5^{\prime}$ & $0.151(11)$ & $-0.08(2)$ & $0.610(10)$ & $0.029 *$ \\
\hline $\mathrm{C} 2$ & $0.6178(11)$ & $0.8992(17)$ & $0.3399(9)$ & $0.014(2)$ \\
\hline $\mathrm{C} 4$ & $0.5248(10)$ & $0.5999(15)$ & $0.2582(9)$ & 0.0092 (19) \\
\hline C6 & $0.7411(10)$ & $0.7538(13)$ & $0.1835(9)$ & $0.011(2)$ \\
\hline $\mathrm{C} 7$ & $0.6120(10)$ & $0.4064(17)$ & $0.1101(10)$ & $0.015(2)$ \\
\hline $\mathrm{C} 8$ & $0.4909(9)$ & $0.311(2)$ & $0.1425(8)$ & $0.0146(17)$ \\
\hline H8 & 0.4487 & 0.1846 & 0.1076 & $0.018^{*}$ \\
\hline $\mathrm{C} 1^{\prime}$ & $0.3008(10)$ & $0.3964(17)$ & $0.2907(10)$ & $0.012(2)$ \\
\hline $\mathrm{H} 1^{\prime}$ & 0.2875 & 0.5169 & 0.3474 & $0.014 *$ \\
\hline $\mathrm{C} 2^{\prime}$ & $0.1592(11)$ & $0.3772(17)$ & $0.2005(10)$ & $0.015(2)$ \\
\hline
\end{tabular}


supporting information

\begin{tabular}{lllll}
$\mathrm{H}^{\prime}{ }^{\prime} 1$ & 0.1835 & 0.3367 & 0.1172 & $0.018^{*}$ \\
$\mathrm{C}^{\prime}$ & $0.0735(10)$ & $0.1976(17)$ & $0.2597(9)$ & $0.0122(19)$ \\
$\mathrm{H}^{\prime} 1$ & 0.077 & 0.0649 & 0.2107 & $0.015^{*}$ \\
$\mathrm{C}^{\prime}$ & $0.1607(10)$ & $0.1677(16)$ & $0.3832(10)$ & $0.015(2)$ \\
$\mathrm{H}^{\prime}$ & 0.1299 & 0.2769 & 0.4412 & $0.017^{*}$ \\
$\mathrm{C}^{\prime}$ & $0.1479(11)$ & $-0.0514(16)$ & $0.4382(10)$ & $0.016(2)$ \\
$\mathrm{H} 5^{\prime} 1$ & 0.0426 & -0.0895 & 0.4389 & $0.019^{*}$ \\
$\mathrm{H} 5^{\prime} 2$ & 0.1947 & -0.157 & 0.388 & $0.019^{*}$ \\
\hline
\end{tabular}

Atomic displacement parameters $\left(\AA^{2}\right)$

\begin{tabular}{|c|c|c|c|c|c|c|}
\hline & $U^{11}$ & $U^{22}$ & $U^{33}$ & $U^{12}$ & $U^{13}$ & $U^{23}$ \\
\hline 17 & $0.0131(3)$ & $0.0142(3)$ & $0.0124(3)$ & $0.0006(3)$ & $0.00485(18)$ & $-0.0025(5)$ \\
\hline N1 & $0.009(4)$ & $0.024(5)$ & $0.010(4)$ & $0.003(3)$ & $0.003(3)$ & $0.001(4)$ \\
\hline $\mathrm{N} 2$ & $0.012(4)$ & $0.016(4)$ & $0.021(5)$ & $-0.002(3)$ & $0.005(3)$ & $-0.003(4)$ \\
\hline N3 & $0.012(4)$ & $0.023(6)$ & $0.011(4)$ & $0.002(3)$ & $0.002(3)$ & $0.000(3)$ \\
\hline N5 & $0.010(4)$ & $0.011(4)$ & $0.009(4)$ & $-0.001(3)$ & $0.001(3)$ & $0.000(3)$ \\
\hline N9 & $0.010(4)$ & 0.015 & 0.008 (4) & -0.001 & $0.003(3)$ & $-0.001(3)$ \\
\hline O6 & $0.014(3)$ & $0.018(5)$ & $0.015(3)$ & $-0.002(2)$ & $0.004(2)$ & $0.002(3)$ \\
\hline $\mathrm{O} 2^{\prime}$ & $0.014(3)$ & $0.013(4)$ & $0.026(4)$ & $0.003(3)$ & $0.001(3)$ & $0.008(3)$ \\
\hline $\mathrm{O}^{\prime}$ & $0.010(3)$ & $0.020(5)$ & $0.017(3)$ & $-0.004(3)$ & $0.004(2)$ & $-0.005(3)$ \\
\hline O4' & $0.011(3)$ & $0.014(3)$ & $0.016(4)$ & $-0.001(3)$ & $0.006(3)$ & $0.005(3)$ \\
\hline O5' & $0.017(4)$ & $0.025(4)$ & $0.017(4)$ & $-0.002(3)$ & $0.003(3)$ & $0.008(3)$ \\
\hline $\mathrm{C} 2$ & $0.016(5)$ & $0.015(5)$ & $0.011(5)$ & $0.003(4)$ & $0.002(4)$ & $0.000(4)$ \\
\hline $\mathrm{C} 4$ & $0.011(4)$ & $0.008(5)$ & $0.008(5)$ & $-0.001(3)$ & $0.000(3)$ & $0.003(4)$ \\
\hline C6 & 0.009 (4) & $0.010(6)$ & $0.015(5)$ & $-0.001(3)$ & $0.000(3)$ & $0.001(4)$ \\
\hline $\mathrm{C} 7$ & $0.013(5)$ & $0.017(5)$ & $0.016(5)$ & $-0.001(4)$ & $0.010(4)$ & $-0.006(4)$ \\
\hline $\mathrm{C} 8$ & $0.015(4)$ & $0.014(5)$ & $0.016(4)$ & $-0.005(6)$ & $0.002(3)$ & $-0.003(7)$ \\
\hline $\mathrm{C} 1^{\prime}$ & $0.011(3)$ & $0.014(3)$ & 0.011 (3) & $-0.001(2)$ & $0.005(2)$ & $-0.001(2)$ \\
\hline $\mathrm{C} 2^{\prime}$ & $0.016(5)$ & $0.018(5)$ & $0.012(5)$ & $0.003(4)$ & $0.003(4)$ & $-0.003(4)$ \\
\hline C3' & $0.010(4)$ & $0.011(4)$ & $0.016(5)$ & $-0.005(4)$ & $0.006(4)$ & $-0.005(4)$ \\
\hline $\mathrm{C} 4^{\prime}$ & $0.014(5)$ & $0.011(5)$ & $0.020(5)$ & $0.002(4)$ & $0.009(4)$ & $0.003(4)$ \\
\hline $\mathrm{C} 5^{\prime}$ & $0.018(5)$ & $0.013(5)$ & $0.018(5)$ & -0.004 (4) & 0.004 (4) & $0.006(4)$ \\
\hline
\end{tabular}

Geometric parameters $\left(A,{ }^{\circ}\right)$

\begin{tabular}{llll}
\hline $\mathrm{I} 7-\mathrm{C} 7$ & $2.081(10)$ & $\mathrm{O} 3^{\prime}-\mathrm{H} 3^{\prime}$ & $0.87(3)$ \\
$\mathrm{N} 1-\mathrm{C} 6$ & $1.345(13)$ & $\mathrm{O} 4^{\prime}-\mathrm{C} 1^{\prime}$ & $1.424(12)$ \\
$\mathrm{N} 1-\mathrm{C} 2$ & $1.359(13)$ & $\mathrm{O} 4^{\prime}-\mathrm{C} 4^{\prime}$ & $1.424(11)$ \\
$\mathrm{N} 2-\mathrm{C} 2$ & $1.336(14)$ & $\mathrm{O} 5^{\prime}-\mathrm{C} 5^{\prime}$ & $1.427(13)$ \\
$\mathrm{N} 2-\mathrm{H} 2 \mathrm{~A}$ & $0.90(3)$ & $\mathrm{O} 5^{\prime}-\mathrm{H} 5^{\prime}$ & $0.87(3)$ \\
$\mathrm{N} 2-\mathrm{H} 2 \mathrm{~B}$ & $0.90(3)$ & $\mathrm{C} 7-\mathrm{C} 8$ & $1.336(14)$ \\
$\mathrm{N} 3-\mathrm{C} 4$ & $1.313(13)$ & $\mathrm{C} 8-\mathrm{H} 8$ & 0.95 \\
$\mathrm{~N} 3-\mathrm{C} 2$ & $1.359(13)$ & $\mathrm{C} 1^{\prime}-\mathrm{C} 2^{\prime}$ & $1.556(14)$ \\
$\mathrm{N} 5-\mathrm{C} 4$ & $1.372(12)$ & $\mathrm{C} 1^{\prime}-\mathrm{H} 1^{\prime}$ & 1.0 \\
$\mathrm{~N} 5-\mathrm{C} 7$ & $1.390(13)$ & $\mathrm{C} 2^{\prime}-\mathrm{C} 3^{\prime}$ & $1.556(15)$ \\
$\mathrm{N} 5-\mathrm{C} 6$ & $1.433(11)$ & $\mathrm{C} 2^{\prime}-\mathrm{H} 2^{\prime} 1$ & 1.0 \\
$\mathrm{~N} 9-\mathrm{C} 4$ & $1.359(13)$ & $\mathrm{C} 3^{\prime}-\mathrm{C} 4^{\prime}$ & $1.521(15)$
\end{tabular}




\begin{tabular}{|c|c|c|c|}
\hline $\mathrm{N} 9-\mathrm{C} 8$ & $1.404(14)$ & $\mathrm{C} 3^{\prime}-\mathrm{H} 3^{\prime} 1$ & 1.0 \\
\hline $\mathrm{N} 9-\mathrm{C} 1^{\prime}$ & $1.439(12)$ & $\mathrm{C} 4^{\prime}-\mathrm{C}^{\prime}$ & $1.520(13)$ \\
\hline $\mathrm{O} 6-\mathrm{C} 6$ & $1.228(12)$ & $\mathrm{C} 4^{\prime}-\mathrm{H} 4^{\prime}$ & 1.0 \\
\hline $\mathrm{O} 2^{\prime}-\mathrm{C} 2^{\prime}$ & $1.408(13)$ & $\mathrm{C} 5^{\prime}-\mathrm{H} 5^{\prime} 1$ & 0.99 \\
\hline $\mathrm{O} 2^{\prime}-\mathrm{H} 2^{\prime}$ & $0.87(3)$ & $\mathrm{C} 5^{\prime}-\mathrm{H} 5^{\prime} 2$ & 0.99 \\
\hline $\mathrm{O} 3^{\prime}-\mathrm{C} 3^{\prime}$ & $1.418(12)$ & & \\
\hline $\mathrm{C} 6-\mathrm{N} 1-\mathrm{C} 2$ & $119.7(9)$ & $\mathrm{O} 4^{\prime}-\mathrm{C} 1^{\prime}-\mathrm{N} 9$ & $109.5(8)$ \\
\hline $\mathrm{C} 2-\mathrm{N} 2-\mathrm{H} 2 \mathrm{~A}$ & $113(9)$ & $\mathrm{O} 4^{\prime}-\mathrm{C} 1^{\prime}-\mathrm{C} 2^{\prime}$ & $105.8(8)$ \\
\hline $\mathrm{C} 2-\mathrm{N} 2-\mathrm{H} 2 \mathrm{~B}$ & $118(9)$ & $\mathrm{N} 9-\mathrm{C} 1^{\prime}-\mathrm{C} 2^{\prime}$ & $115.9(9)$ \\
\hline $\mathrm{H} 2 \mathrm{~A}-\mathrm{N} 2-\mathrm{H} 2 \mathrm{~B}$ & $125(10)$ & $\mathrm{O} 4^{\prime}-\mathrm{C} 1^{\prime}-\mathrm{H} 1^{\prime}$ & 108.5 \\
\hline $\mathrm{C} 4-\mathrm{N} 3-\mathrm{C} 2$ & $112.8(8)$ & $\mathrm{N} 9-\mathrm{C} 1^{\prime}-\mathrm{H} 1^{\prime}$ & 108.5 \\
\hline $\mathrm{C} 4-\mathrm{N} 5-\mathrm{C} 7$ & $109.0(8)$ & $\mathrm{C} 2^{\prime}-\mathrm{C} 1^{\prime}-\mathrm{H} 1^{\prime}$ & 108.5 \\
\hline $\mathrm{C} 4-\mathrm{N} 5-\mathrm{C} 6$ & $118.7(8)$ & $\mathrm{O} 2^{\prime}-\mathrm{C} 2^{\prime}-\mathrm{C} 1^{\prime}$ & $104.5(8)$ \\
\hline $\mathrm{C} 7-\mathrm{N} 5-\mathrm{C} 6$ & $132.3(8)$ & $\mathrm{O} 2^{\prime}-\mathrm{C} 2^{\prime}-\mathrm{C} 3^{\prime}$ & $115.7(8)$ \\
\hline $\mathrm{C} 4-\mathrm{N} 9-\mathrm{C} 8$ & $107.9(8)$ & $\mathrm{C} 1^{\prime}-\mathrm{C} 2^{\prime}-\mathrm{C} 3^{\prime}$ & $101.9(8)$ \\
\hline $\mathrm{C} 4-\mathrm{N} 9-\mathrm{C} 1^{\prime}$ & $123.7(8)$ & $\mathrm{O} 2^{\prime}-\mathrm{C} 2^{\prime}-\mathrm{H} 2^{\prime} 1$ & 111.4 \\
\hline $\mathrm{C} 8-\mathrm{N} 9-\mathrm{C} 1^{\prime}$ & $127.9(9)$ & $\mathrm{C} 1^{\prime}-\mathrm{C} 2^{\prime}-\mathrm{H} 2^{\prime} 1$ & 111.4 \\
\hline $\mathrm{C} 2^{\prime}-\mathrm{O} 2^{\prime}-\mathrm{H} 2^{\prime}$ & $112(9)$ & $\mathrm{C} 3^{\prime}-\mathrm{C} 2^{\prime}-\mathrm{H} 2^{\prime} 1$ & 111.4 \\
\hline $\mathrm{C} 3^{\prime}-\mathrm{O} 3^{\prime}-\mathrm{H} 3^{\prime}$ & $113(9)$ & $\mathrm{O} 3^{\prime}-\mathrm{C} 3^{\prime}-\mathrm{C} 4^{\prime}$ & $112.3(8)$ \\
\hline $\mathrm{C} 1^{\prime}-\mathrm{O} 4^{\prime}-\mathrm{C} 4^{\prime}$ & $103.7(7)$ & $\mathrm{O} 3^{\prime}-\mathrm{C} 3^{\prime}-\mathrm{C} 2^{\prime}$ & $111.5(8)$ \\
\hline $\mathrm{C} 5^{\prime}-\mathrm{O} 5^{\prime}-\mathrm{H} 5^{\prime}$ & $109(9)$ & $\mathrm{C} 4^{\prime}-\mathrm{C} 3^{\prime}-\mathrm{C} 2^{\prime}$ & $103.2(8)$ \\
\hline $\mathrm{N} 2-\mathrm{C} 2-\mathrm{N} 3$ & $116.2(9)$ & $\mathrm{O} 3^{\prime}-\mathrm{C} 3^{\prime}-\mathrm{H} 3^{\prime} 1$ & 109.9 \\
\hline $\mathrm{N} 2-\mathrm{C} 2-\mathrm{N} 1$ & $117.1(9)$ & $\mathrm{C} 4^{\prime}-\mathrm{C} 3^{\prime}-\mathrm{H} 3^{\prime} 1$ & 109.9 \\
\hline $\mathrm{N} 3-\mathrm{C} 2-\mathrm{N} 1$ & $126.7(10)$ & $\mathrm{C} 2^{\prime}-\mathrm{C} 3^{\prime}-\mathrm{H} 3^{\prime} 1$ & 109.9 \\
\hline $\mathrm{N} 3-\mathrm{C} 4-\mathrm{N} 9$ & $126.8(9)$ & $\mathrm{O} 4^{\prime}-\mathrm{C} 4^{\prime}-\mathrm{C} 5^{\prime}$ & $109.6(8)$ \\
\hline $\mathrm{N} 3-\mathrm{C} 4-\mathrm{N} 5$ & $126.0(9)$ & $\mathrm{O} 4^{\prime}-\mathrm{C} 4^{\prime}-\mathrm{C} 3^{\prime}$ & $103.6(8)$ \\
\hline $\mathrm{N} 9-\mathrm{C} 4-\mathrm{N} 5$ & $107.2(8)$ & $\mathrm{C} 5^{\prime}-\mathrm{C} 4^{\prime}-\mathrm{C} 3^{\prime}$ & $114.7(9)$ \\
\hline $\mathrm{O} 6-\mathrm{C} 6-\mathrm{N} 1$ & $125.1(8)$ & $\mathrm{O} 4^{\prime}-\mathrm{C} 4^{\prime}-\mathrm{H} 4^{\prime}$ & 109.6 \\
\hline $\mathrm{O} 6-\mathrm{C} 6-\mathrm{N} 5$ & $118.8(8)$ & $\mathrm{C} 5^{\prime}-\mathrm{C} 4^{\prime}-\mathrm{H} 4^{\prime}$ & 109.6 \\
\hline $\mathrm{N} 1-\mathrm{C} 6-\mathrm{N} 5$ & $116.1(8)$ & $\mathrm{C} 3^{\prime}-\mathrm{C} 4^{\prime}-\mathrm{H} 4^{\prime}$ & 109.6 \\
\hline $\mathrm{C} 8-\mathrm{C} 7-\mathrm{N} 5$ & $107.3(9)$ & $\mathrm{O} 5^{\prime}-\mathrm{C} 5^{\prime}-\mathrm{C} 4^{\prime}$ & $110.3(8)$ \\
\hline $\mathrm{C} 8-\mathrm{C} 7-\mathrm{I} 7$ & $125.8(8)$ & $\mathrm{O} 5^{\prime}-\mathrm{C} 5^{\prime}-\mathrm{H} 5^{\prime} 1$ & 109.6 \\
\hline $\mathrm{N} 5-\mathrm{C} 7-\mathrm{I} 7$ & $126.9(7)$ & $\mathrm{C} 4^{\prime}-\mathrm{C} 5^{\prime}-\mathrm{H} 5^{\prime} 1$ & 109.6 \\
\hline $\mathrm{C} 7-\mathrm{C} 8-\mathrm{N} 9$ & $108.6(10)$ & $\mathrm{O} 5^{\prime}-\mathrm{C} 5^{\prime}-\mathrm{H} 5^{\prime} 2$ & 109.6 \\
\hline $\mathrm{C} 7-\mathrm{C} 8-\mathrm{H} 8$ & 125.7 & $\mathrm{C} 4^{\prime}-\mathrm{C} 5^{\prime}-\mathrm{H} 5^{\prime} 2$ & 109.6 \\
\hline $\mathrm{N} 9-\mathrm{C} 8-\mathrm{H} 8$ & 125.7 & $\mathrm{H} 5^{\prime} 1-\mathrm{C} 5^{\prime}-\mathrm{H} 5^{\prime} 2$ & 108.1 \\
\hline $\mathrm{C} 4-\mathrm{N} 3-\mathrm{C} 2-\mathrm{N} 2$ & $-178.0(9)$ & $\mathrm{I} 7-\mathrm{C} 7-\mathrm{C} 8-\mathrm{N} 9$ & $177.9(7)$ \\
\hline $\mathrm{C} 4-\mathrm{N} 3-\mathrm{C} 2-\mathrm{N} 1$ & $2.7(14)$ & $\mathrm{C} 4-\mathrm{N} 9-\mathrm{C} 8-\mathrm{C} 7$ & $1.8(12)$ \\
\hline $\mathrm{C} 6-\mathrm{N} 1-\mathrm{C} 2-\mathrm{N} 2$ & $178.5(9)$ & $\mathrm{C} 1{ }^{\prime}-\mathrm{N} 9-\mathrm{C} 8-\mathrm{C} 7$ & $173.1(10)$ \\
\hline $\mathrm{C} 6-\mathrm{N} 1-\mathrm{C} 2-\mathrm{N} 3$ & $-2.3(15)$ & $\mathrm{C} 4^{\prime}-\mathrm{O} 4^{\prime}-\mathrm{C} 1^{\prime}-\mathrm{N} 9$ & $-166.9(9)$ \\
\hline $\mathrm{C} 2-\mathrm{N} 3-\mathrm{C} 4-\mathrm{N} 9$ & $178.8(9)$ & $\mathrm{C} 4^{\prime}-\mathrm{O} 4^{\prime}-\mathrm{C} 1^{\prime}-\mathrm{C} 2^{\prime}$ & $-41.3(9)$ \\
\hline $\mathrm{C} 2-\mathrm{N} 3-\mathrm{C} 4-\mathrm{N} 5$ & $-1.0(13)$ & $\mathrm{C} 4-\mathrm{N} 9-\mathrm{Cl}^{\prime}-\mathrm{O} 4^{\prime}$ & $-120.6(9)$ \\
\hline $\mathrm{C} 8-\mathrm{N} 9-\mathrm{C} 4-\mathrm{N} 3$ & $179.1(9)$ & $\mathrm{C} 8-\mathrm{N} 9-\mathrm{C} 1^{\prime}-\mathrm{O} 4^{\prime}$ & $69.3(12)$ \\
\hline $\mathrm{C} 1{ }^{\prime}-\mathrm{N} 9-\mathrm{C} 4-\mathrm{N} 3$ & $7.4(15)$ & $\mathrm{C} 4-\mathrm{N} 9-\mathrm{C} 1^{\prime}-\mathrm{C} 2^{\prime}$ & $119.8(10)$ \\
\hline $\mathrm{C} 8-\mathrm{N} 9-\mathrm{C} 4-\mathrm{N} 5$ & $-1.0(10)$ & $\mathrm{C} 8-\mathrm{N} 9-\mathrm{C} 1^{\prime}-\mathrm{C} 2^{\prime}$ & $-50.3(14)$ \\
\hline $\mathrm{C} 11^{\prime}-\mathrm{N} 9-\mathrm{C} 4-\mathrm{N} 5$ & $-172.8(9)$ & $\mathrm{O} 4^{\prime}-\mathrm{C} 1^{\prime}-\mathrm{C} 2^{\prime}-\mathrm{O} 2^{\prime}$ & $138.9(8)$ \\
\hline
\end{tabular}




$$
\begin{aligned}
& \mathrm{C} 7-\mathrm{N} 5-\mathrm{C} 4-\mathrm{N} 3 \\
& \mathrm{C} 6-\mathrm{N} 5-\mathrm{C} 4-\mathrm{N} 3 \\
& \mathrm{C} 7-\mathrm{N} 5-\mathrm{C} 4-\mathrm{N} 9 \\
& \mathrm{C} 6-\mathrm{N} 5-\mathrm{C} 4-\mathrm{N} 9 \\
& \mathrm{C} 2-\mathrm{N} 1-\mathrm{C} 6-\mathrm{O} 6 \\
& \mathrm{C} 2-\mathrm{N} 1-\mathrm{C} 6-\mathrm{N} 5 \\
& \mathrm{C} 4-\mathrm{N} 5-\mathrm{C} 6-\mathrm{O} 6 \\
& \mathrm{C} 7-\mathrm{N} 5-\mathrm{C} 6-\mathrm{O} 6 \\
& \mathrm{C} 4-\mathrm{N} 5-\mathrm{C} 6-\mathrm{N} 1 \\
& \mathrm{C} 7-\mathrm{N} 5-\mathrm{C} 6-\mathrm{N} 1 \\
& \mathrm{C} 4-\mathrm{N} 5-\mathrm{C} 7-\mathrm{C} 8 \\
& \mathrm{C} 6-\mathrm{N} 5-\mathrm{C} 7-\mathrm{C} 8 \\
& \mathrm{C} 4-\mathrm{N} 5-\mathrm{C} 7-\mathrm{I} 7 \\
& \mathrm{C} 6-\mathrm{N} 5-\mathrm{C} 7-\mathrm{I} 7 \\
& \mathrm{~N} 5-\mathrm{C} 7-\mathrm{C} 8-\mathrm{N} 9
\end{aligned}
$$

$179.8(9)$
$-1.0(14)$
$-0.1(10)$
$179.2(7)$
$178.7(9)$
$0.0(13)$
$-177.3(8)$
$1.7(15)$
$1.5(12)$
$-179.5(9)$
$1.1(11)$
$-177.9(10)$
$-178.5(7)$
$2.4(15)$
$-1.8(12)$

$-99.5(10)$

$18.1(9)$

$139.7(9)$

$17.9(12)$

$130.6(8)$

$-102.8(9)$

$9.8(10)$

$170.7(8)$

$47.8(9)$

$-155.0(8)$

$-34.8(9)$

$85.5(10)$

$-154.3(8)$

$71.0(10)$

$-172.9(8)$

Hydrogen-bond geometry $\left(A,{ }^{\circ}\right)$

\begin{tabular}{lllll}
\hline$D-\mathrm{H} \cdots A$ & $D-\mathrm{H}$ & $\mathrm{H} \cdots A$ & $D \cdots A$ & $D-\mathrm{H}^{\cdots} A$ \\
\hline $\mathrm{N} 2-\mathrm{H} 2 A \cdots \mathrm{O} 4^{\prime \mathrm{i}}$ & $0.90(3)$ & $2.25(10)$ & $2.941(11)$ & $133(11)$ \\
$\mathrm{N} 2-\mathrm{H} 2 B^{\cdots} \cdots 5^{\prime}$ & $0.90(3)$ & $2.04(5)$ & $2.905(12)$ & $160(12)$ \\
$\mathrm{O}^{\prime}-\mathrm{H}^{\prime} \cdots 6^{\text {iii }}$ & $0.87(3)$ & $1.93(8)$ & $2.689(9)$ & $144(12)$ \\
$\mathrm{O}^{\prime}-\mathrm{H}^{\prime} \cdots 3^{\prime i \mathrm{iv}}$ & $0.87(3)$ & $1.87(7)$ & $2.673(10)$ & $151(13)$ \\
$\mathrm{C}^{\prime}-\mathrm{H} 1^{\prime} \cdots \mathrm{N} 2^{\mathrm{v}}$ & 1.0 & 2.63 & $3.345(15)$ & 128 \\
$\mathrm{C}^{\prime}-\mathrm{H}^{\prime}{ }^{\prime} \cdots 6^{\mathrm{vi}}$ & 1.0 & 2.57 & $3.541(12)$ & 163
\end{tabular}

Symmetry codes: (i) $x, y+1, z$; (ii) $-x+1, y+3 / 2,-z+1$; (iii) $x-1, y, z$; (iv) $-x, y-1 / 2,-z+1$; (v) $-x+1, y-1 / 2,-z+1$; (vi) $-x+1, y-1 / 2,-z$. 